\title{
Arte y religión en Schopenhauer: de la necesidad metafísica a la justificación estética de la existencia*
}

Encarnación Ruiz Callejón**

\section{Resumen}

La tesis que desarrollo en este trabajo es que en Schopenhauer existe una vía de afirmación de la existencia y del mundo asumiendo la ausencia de fundamento, una justificación estética de la existencia o arte de vivir en la línea de un pesimismo trágico o de la fortaleza. Este camino adicional a su posición fundamental en El mundo como voluntad y representación aparece claramente en Parerga y Paralipómena, especialmente en "Sobre la religión» y en los «Aforismos sobre la sabiduría de la vida». Para desarrollar esa tesis, analizo el concepto de «necesidad metafísica» y su relación con el arte y con el proyecto de filosofía en el autor.

\section{Palabras clave}

Arte, necesidad metafísica, pesimismo trágico, religión.

\footnotetext{
Este es uno de los artículos que ha desarrollado como miembro del Proyecto FFI2010-16650, financiado por el Ministerio Español de Innovación y Ciencia.

** $\quad$ Profesora Ayudante Doctora. Departamento de Filosofía II. Universidad de Granada (España). Actualmente pertenece al proyecto de investigación: «Las pasiones y la naturaleza humana: razón, creencias y emociones en los conflictos de valores» (Referencia: FFI2010-16650). Y al grupo de investigación: «Sujeto, identidad e interculturalidad en el marco de una sociedad pluralista y mundial. Perspectivas antropológicas y filosóficas». Antropología y Filosofía (Código: SEJ 126). Contacto: ruizencarnacion@ugr.es.
} 


\title{
Art and Religion in Schopenhauer: From Metaphysical Necessity to the Aesthetic Justification of Existence
}

\begin{abstract}
The thesis that I develop in this paper is that there is a way of affirmation of the existence and the world in Schopenhauer, assuming no foundation, an aesthetic justification of existence or a way of life either as a tragic pessimism or pessimism of strength. This is an additional path to his basic position stated in The World as Will and Representation and is clearly in Parerga and Paralipomena, especially in «On Religion» and in "Aphorisms on the wisdom of life». To develop that thesis, I analyze the concept of «need for metaphysics» and its relationship to art and to the author's project of philosophy.
\end{abstract}

\section{Keywords}

Art, need for metaphysics, tragic pessimism, religion.

\section{La necesidad metafísica y sus gestores}

El historiador israelí Élie Barnavi cuestiona en Las religiones asesinas la afirmación nietzscheana de la muerte de Dios al hilo de la buena salud de la religión en nuestro tiempo, y se pregunta cómo esta «ilusión», «cuya desaparición no ha cesado de predecir el Occidente racionalista, resiste triunfante donde las grandes utopías laicas nacidas de la modernidad han mordido el polvo» ${ }^{1}$. Destaca al respecto la extraordinaria polisemia y versatilidad de la religión:

1 Élie Barnavi, Las religiones asesinas (Madrid: Turner, 2007). 
abarca creencias y mitos, prácticas e instituciones, textos y tradiciones, lugares e itinerarios, la violencia del sacrificio y el consuelo de la oración, la fraternidad de los fieles y la guerra contra el infiel, imágenes de dioses y de santos, de héroes y villanos. También es una estructura de poder, una trama de intercambios, una cuadrícula para interpretar el mundo, un bálsamo contra la angustia existencial del individuo y de la colectividad. Es, por último, un sistema simbólico abastecedor de sentido, de esperanza, de valores y de identidad, y, precisamente por eso, la religión genera tanta violencia: estas cosas son lo suficientemente importantes como para que merezca la pena matar y dejarse matar por ellas ${ }^{2}$.

La pervivencia, la polisemia y la extraordinaria ambivalencia del hecho religioso es lo que Schopenhauer también puso de relieve a propósito de la necesidad metafísica, un tema que aborda en el capítulo 17 de los Complementos a El mundo como voluntad y representación y en el capítulo «Sobre la religión» de Parerga y Paralipómena. El texto de los Complementos amplía el parágrafo 15 del Libro I de El mundo como voluntad y representación. En este parágrafo se refería a la intuición inmediata, frente a la empírica, como «fundamento último y la fuente de toda verdad ${ }^{3}$, a la limitación de la ciencia a una explicación de la realidad, y a cómo la filosofía retoma el camino donde la ciencia acaba.

El hombre es un animal metafísico, el único ser que se asombra de su existencia y de la del mundo. La pregunta metafísica responde a una necesidad, en el doble sentido de penuria y exigencia, y supone ciertas condiciones: la admiración filosófica implica una actitud reflexiva, pero sobre todo la existencia del sufrimiento y de la muerte. Por lo que dicha admiración es, ante todo, consternación ${ }^{4}$. La necesidad metafísica no es ajena tampoco a una tensión trágica a la que ya había hecho referencia Kant: «la razón humana tiene el destino singular, en uno de sus campos de conocimiento, de hallarse acosada por cuestiones que no puede

Ibíd., 20-21.

Arthur Schopenhauer, El mundo como voluntad y representación (Madrid: Trotta, 2004), 128. Arthur Schopenhauer, Werke in zehn Bänden. Bd: I. (Zürich: Diogenes Verlag, 1977), 117 (en adelante: W seguido del volumen y la página).

4 Schopenhauer, Arthur. El mundo como voluntad y representación. Complementos (Madrid: Trotta, 2003), 223 (W III, 200). 
rechazar, por ser planteadas por la misma naturaleza de la razón, pero a las que tampoco puede responder por sobrepasar todas sus facultades» ${ }^{5}$. Schopenhauer también inicia su reflexión partiendo de la concepción de la filosofía como investigación sobre las condiciones de posibilidad de la experiencia (investigación trascendental) ${ }^{6}$. E insiste en que su filosofía es una «ciencia de la experiencia». Pero profundiza en el giro kantiano al señalar que la Crítica de la razón pura permanece incompleta sin un estudio de la fisiología, del cuerpo del que dependen las facultades ${ }^{7}$. Nuestros conocimientos fundamentales a priori (espacio, tiempo y causalidad, según Schopenhauer) pueden considerarse como un capítulo de la fisiología del cerebro ${ }^{8}$. Por otro lado, no somos sólo sujetos que conocen objetos. Kant no reparó en otro tipo de experiencia: la del propio cuerpo, la interna. Mi cuerpo es lo que inmediatamente experimento, siento. Y además es la condición de posibilidad, el punto de partida y la referencia para cualquier otro conocimiento. En la introspección ${ }^{9}$ tenemos otra experiencia de nosotros como movimiento, actividad, espontaneidad, deseo. Schopenhauer llama a esto «voluntad». Somos, pues, ambas cosas: un sujeto que representa y voluntad. Y esto significa que tenemos dos claves para explicar la realidad: representación y voluntad ${ }^{10}$. Así, si partimos de lo más conocido y rechazamos además el solipsismo, tendremos que concluir -por analogía- que también el mundo en

Schopenhauer desarrolla otra dimensión de la trascendentalidad: «La concepción de las cosas por medio y con arreglo a dichas condiciones es la concepción inmanente; por el contrario, aquella que se da cuenta de las condiciones mismas es la concepción trascendental. Esta solo se comprende en abstracto por la crítica de la razón pura; pero excepcionalmente también puede comprenderse intuitivamente. Esto último constituye mi añadido...». Arthur Schopenhauer, El mundo como voluntad y representación, op. cit., 227. (W I, 225-226).

7 «Una filosofía que, como kantiana, ignore totalmente este aspecto del intelecto, es parcial y por ello insuficiente. Abre entre nuestro saber filosófico y fisiológico un abismo insondable con el que nunca nos podemos sentir satisfechos». Ibíd., 314. (W III, 319). Ibíd., 77. (W III, 59).

En el sentido de «mirar adentro», atender a las noticias que tenemos de nosotros desde ahí, que en Schopenhauer será atender a cómo experimentamos, sentimos, nuestro cuerpo.

10 «¿̇Pues qué otra clase de existencia o realidad deberíamos atribuir al resto del mundo corpóreo? ¿̇De dónde habríamos de tomar los elementos con que componerlo? Fuera de la voluntad y de la representación no conocemos ni podemos pensar nada». Ibíd., 157 (W I, 159). 
general puede ser entendido como voluntad y representación. Y esta es la propuesta de Schopenhauer y la forma en que completa a Kant sin traicionar el espíritu de su filosofía. En realidad, no tenemos experiencia de otra cosa distinta a la representación o a la voluntad. Schopenhauer especifica, sin embargo, que utiliza la palabra «voluntad» por deferencia al sujeto y porque es la expresión más adecuada que encuentra para significar el movimiento o espontaneidad interior ${ }^{11}$. Pero si interpretamos por analogía que los demás fenómenos tienen que ser de nuestra misma naturaleza, el mundo no sólo es un macrántropos ${ }^{12}$, sino que el sujeto mismo es ahora fundamentalmente un intérprete, un hermeneuta.

La voluntad es un movimiento sin finalidad que eternamente se manifiesta en distintos grados a los que Schopenhauer llama Ideas. La irrupción, en el sentido de expresión u objetivación, de la voluntad en el fenómeno, es el mundo como representación, el mundo fenoménico. La voluntad es también el núcleo y motor interno del individuo. Todo es interiormente voluntad, aunque no siempre esta vaya acompañada de conciencia. Esto último sólo ocurre en el hombre, cuya vida transcurre entre el deseo (que no es sino una forma más de sufrimiento porque es carencia) y el aburrimiento, pues la desilusión sigue al cumplimiento de un deseo que, una vez obtenido, muestra que tampoco era eso lo que ansiaba la voluntad. La esencia del sujeto es el desfondamiento y la aspiración a la felicidad es una gran ilusión, un error innato del que más vale deshacerse lo más pronto posible. No sabemos el sentido de esta tragicomedia que para nosotros se corona con la muerte. Pero ni la voluntad es Dios ni el mundo ninguna teofanía, sino el campo de expresión y batalla de un movimiento ciego que eternamente se manifiesta y devora a

11 «La palabra Wille no fue siquiera la primera palabra que eligió. Antes eligió Kraft, 'fuerza'. Pero después de muchas dudas rechazó Kraft basándose en que su principal connotación como término técnico pertenecía al reino de las ciencias naturales y que estas corresponden exclusivamente al mundo de los fenómenos». Bryan Magee, Schopenhauer (Madrid: Cátedra, 1991), 429.

12 Arthur Schopenhauer, El mundo como voluntad y representación. Complementos, op. cit., 701. (W IV, 753). 
sí mismo ${ }^{13}$. Como ha señalado Remedios Ávila, Schopenhauer se hace eco también de otro sentido de la representación inspirado en el Barroco y en la literatura: el mundo se considera como una gran representación teatral y como un sueño (La vida es sueño). El hombre es un ser empujado a ese escenario sin saber por qué ni para qué. Le toca representar un papel que él no ha escrito y que casi nunca tiene sentido, pero cuyas consecuencias sí que padece. Lo único seguro es que al final caerá el telón. Para entender qué es el mundo en ambos sentidos de la representación (un conjunto de fenómenos para un sujeto y un escenario), la ciencia no es suficiente, aunque sea absolutamente necesaria y útil pues explica el mundo fenoménico, desmonta falsas concepciones y señala y subsana errores. Pero habla de fenómenos o de relaciones entre ellos, y admite siempre algo dado, o sea: describe la realidad, pero no la interpreta, no nos dice qué es. En la ciencia no encontramos respuestas a nuestras preguntas por el sentido.

Hay que señalar en Schopenhauer también la influencia platónica, asociada a la búsqueda de la trascendencia y a la conversión. Kant representaba para él más bien el crítico de los excesos de la metafísica; Platón, la persistencia de la necesidad metafísica. Otra influencia es el neoplatonismo. Según el autor, los filósofos neoplatónicos habrían asimilado la sabiduría indo-egipcia y la habrían traducido a caracteres platónicos, subrayado la precariedad de nuestra existencia, pero también nuestra vocación y proyección hacia la esperanza y la trascendencia: «No somos los que deberíamos y querríamos ser, por lo que siempre esperamos del futuro algo mejor y aguardamos la satisfacción de nuestra carencia, de donde nace el futuro y su condición: el tiempo» ${ }^{14}$.

Según Maceiras Fafián, la voluntad sería en realidad una metáfora de una noción nueva y tendría que ver más con concepciones científicas que con postulados metafísicos. Schopenhauer se aproximaría a un monismo energetista inspirado en la investigación científica de finales del XVIII y de todo el XIX. La voluntad no es asimilable al concepto de vida, sino al de energía que él intuye como exigencia, en su tiempo teórica, para explicar los fenómenos de la Naturaleza. Schopenhauer sería un precedente de la búsqueda de una teoría para unificar todas las fuerzas fundamentales de la naturaleza. Manuel Maceiras Fafián, «La Voluntad como energía», Logos. Anales del Seminario de Metafísica 23 (1989): 119-134.

14 Arthur Schopenhauer, «Fragmentos sobre la historia de la filosofía» en Parerga y Paralipómena I. (Madrid: Trotta, 2006), 93. (W VII, 73). 
Schopenhauer afirma que hay dos caminos para responder a la exigencia de sentido, dos formas de metafísica: la religión y la filosofía. La religión se acredita desde fuera al depender de la revelación y se expresa en un lenguaje alegórico. En ella encontramos fe, textos sagrados, autoridades, mitos, dogmas, misterios, hechos extraordinarios. La filosofía, por el contrario, busca la verdad en sentido estricto. Es reflexiva y opera con conceptos y argumentos. Lo cuestiona todo y no da nada por sabido. Exige gran capacidad de reflexión y una amplia formación, mucho tiempo, esfuerzo y compromiso. Esto la convierte en un camino accesible a muy pocos y ni siquiera se da en todas las culturas. Schopenhauer la denomina «ciencia de la experiencia» porque parte de esta y la transcribe en conceptos. Pero el conjunto de la experiencia es sólo un conjunto de fenómenos que hay que interpretar, cuyo trasfondo hay que desvelar, ver qué lo sostiene, qué significa. Por eso la filosofía es la interpretación del mundo, la respuesta a la pregunta: ¿̇qué es el mundo? La filosofía es sobre todo metafísica ${ }^{15}$ y esta una ciencia hermenéutica.

No han faltado, sin embargo, quienes han hecho de la necesidad metafísica un medio lucrativo. Según el autor, este sería el caso del estamento religioso y de los profesores de filosofía. El primero ha monopolizado y administrado la necesidad metafísica inculcando sus dogmas en la infancia. Schopenhauer se refiere a los sacerdotes como a una mezcla de estafadores y maestros de costumbres. Su opinión sobre los profesores de filosofía no es mejor ${ }^{16}$, porque la dedicación a esta solo puede ser vocacional y jamás una profe$\operatorname{sión}^{17}$ : se ha de vivir para la filosofía y no de ella. Quien vive de

«...la metafísica va más allá del fenómeno, es decir, de la naturaleza, hasta aquello que se esconde en o tras de ella (...), pero considerándolo siempre como lo que en ella se manifiesta, y no con independencia del fenómeno: por eso sigue siendo inmanente y nunca trascendente (...) no habla de la cosa en sí más que en su relación con el fenómeno». Arthur Schopenhauer, El mundo como voluntad y representación. Complementos, op. cit., 222. (W III, 214). Schopenhauer entiende por "metafísica»: «todo presunto conocimiento que va más allá de la posibilidad de la experiencia, o sea, de la naturaleza o del fenómeno dado de las cosas, para ofrecer una clave (...) sobre aquello que se oculta tras la naturaleza y la hace posible». Ibíd., 202. (W III, 191).

16 Y en este caso se trata también de un diagnóstico de la filosofía de la época no exento de un trasfondo personal motivado por su paso sin éxito por la docencia universitaria.

Algo que él se podía permitir con su condición de rentista. 
ella, traiciona su espíritu y ha de pagar ciertos tributos como ser bufón de los reyes; transmitir verdades de catecismo camufladas; vivir constantemente preocupado por la marcha del oficio (por el ascenso social, por ser brillante, etc.) dejando a un lado lo único importante: la búsqueda desinteresada de la verdad. Así, entiende que la filosofía de la época (que personaliza en Fichte, Schelling y especialmente Hegel) ha olvidado qué es la filosofía y también las firmes bases con las que Kant la dotó. Es solo un sofisticado edificio conceptual, una logomaquia. Está rendida al poder y al orden establecido y se ha mercantilizado ${ }^{18}$. Por eso dice que su época será citada como el "período de la deshonestidad»" ${ }^{19}$. Un mal añadido es que el filósofo se ha convertido en un erudito, en un "pensador libresco»: registra lo que uno ha dicho, lo que otro interpretó, las reservas de un tercero. Compara, pesa, critica, pero es incapaz de pensar por sí mismo y generar conocimiento. La erudición es una pesada coraza que anula a la mayoría de los individuos ${ }^{20}$. El filósofo auténtico, por el contrario, vive la filosofía como una vocación independiente de todos los poderes establecidos y de cualquier honor. Como cualquier espíritu libre ${ }^{21}$, se alimenta y renueva constantemente con su experiencia personal del mundo, no con conceptos o ideas prestadas ${ }^{22}$, y a partir de ahí responde al enigma de la existencia.

18 Toda esta reflexión estará muy presente en el escrito del joven Nietzsche sobre el futuro de los centros de enseñanza alemanes.

19 Arthur Schopenhauer, «Sobre el fundamento de la moral» en Los dos problemas fundamentales de la ética. (Madrid: Siglo XXI, 1993), 174. (WVI, 187).

20 «La peluca constituye un signo inminente de la pura erudición en cuanto tal: adorna su cabeza con una pródiga mata de cabello ajeno para suplir la carencia del propio, al igual que la erudición colma su ajuar con un inmenso lote de pensamientos extraños». Arthur Schopenhauer, Manuscritos berlineses. Sentencias y aforismos (Antología) (Valencia: Pre-Textos, 1996), 87. Der handschriftliche Nachlass in fünf Bänden. Bd: III. (München: Deutscher Taschenbuch Verlag, München, 1985), 9596, [52]) (en adelante: $H N$, seguida del tomo, la página y la anotación).

21 «El pienso de los profesores está destinado más bien a los rumiantes. Quienes reciben sus propias presas de manos de la naturaleza permanecen en libertad». Ibíd., 132. (HN III, 193, [16]).

22 «Los que esperan convertirse en filósofos estudiando historia de la filosofía deberían más bien inferir de ella que los filósofos, exactamente igual que los poetas, solo nacen y, por cierto, muy raramente». Arthur Schopenhauer, «Sobre la filosofía y su método», en Parerga y Paralipómena II (Madrid: Trotta, 2009), 38. (W IX, 14). 


\section{El diálogo entre Demófeles («el amigo del pueblo») y Filaletes («el amigo de la verdad»)}

«Sobre la religión» es uno de los textos que integran Parerga y Paralipómena. Schopenhauer había trabajado en esta obra, publicada en 1851, entre 1845 y $1850^{23}$. El diálogo entre Demófeles y Filaletes ocupa la mayor parte de ese texto. Quiero detenerme en él porque Schopenhauer profundiza con mucho detalladamente en el estatuto y características de las dos formas de satisfacer la necesidad metafísica, especialmente en la religión, pero sobre todo porque el autor adopta aquí, y en otros textos de Parerga a los que me referiré, una perspectiva con importantes consecuencias para la valoración de su filosofía. Esta perspectiva, que prescinde de la negación de la voluntad, no está presente en su meditación sobre la necesidad metafísica en su obra fundamental y no ha sido analizada ${ }^{24}$. Es necesario decir que el diálogo entre los dos personajes ocupa un lugar discreto en su producción. No aparece en la obra fundamental, ni siquiera en los Complementos, y sin embargo, constituye una reflexión profunda y matizada sobre la relación entre filosofía y religión, sobre el valor y aspectos de la verdad, y sobre las dimensiones psicológicas, sociopolíticas y culturales del fenómeno religioso. En la época, el reencuentro de Europa con las culturas orientales supuso también la traducción y difusión de los textos de otras religiones. Schopenhauer no solo se interesó por la sabiduría oriental, sino que formó parte del grupo de pensadores e intelectuales, especialmente alemanes, que reaccionaron, si bien con diferencias, a la crisis de valores de su tiempo buscando en Oriente (a veces un Oriente ideal y monolítico) desde la renovación

23 Schopenhauer previó una segunda edición corregida y con añadidos que, sin embargo, no alcanzó a llevar a cabo, por ello, determinar el texto definitivo de la obra ha sido uno de los escollos fundamentales a la hora de editarla. Diego Sánchez Meca, «Estudio preliminar», en A. Schopenhauer, El dolor del mundo y el consuelo de la religión (Paralipomena 134-182) (Madrid: Alderabán, 1998), 78.

24 Apenas es tratada, por ejemplo, por Karl W. Wilhelm, Zwischen Allwissenheitslehre und Verzweiflung: der Ort der Religion in der Philosophie Schopenhauers (Hildesheim; New York: G. Olms, 1994); Alfred Schmidt, Die Wahrheit im Gewande der Luge: Schopenhauers Religionsphilosophie (Múnich, Zúrich: Piper, 1986); Gerard Mannion, Schopenhauer, Religion and Morality. The Humble Path to Ethics. (England: Ashgate Publishing Limited, 2003), Konstantin o Broese at al. (Hrsg.). Die Deutung der Welt. Jörg Salaquardas Schriften zu Arthur Schopenhauer (Würzburg: Verlag Königshausen \& Neumann $\mathrm{GmbH}, 2007)$, especialmente el apartado II. 
cultural hasta la recuperación de un saber primigenio, pasando por una alternativa al racionalismo y pragmatismo ilustrados, o incluso una vía que ponía en cuestión la hegemonía de la herencia griega en el pensamiento occidental o que Grecia haya sido la única cuna de la filosofía ${ }^{25}$. Por otro lado, las consideraciones de Schopenhauer sobre la religión son significativas para nuestro tiempo y no solo porque inciden en la ambigüedad del fenómeno religioso. Abren una perspectiva transcultural. La religión se ha globalizado, los altares forman parte del equipaje de los movimientos de emigración, como señala Barnavi ${ }^{26}$. Y tenemos grandes retos pendientes: el diálogo interreligioso y la coexistencia en sociedades cada vez más plurales; desactivar el fanatismo y promover la tolerancia y la comprensión. Es decir, estamos obligados a replantearnos el lugar de la religión en nuestro tiempo. En el diálogo se profundiza, además, en la posición del autor acerca de la necesidad metafísica y en su relación con la verdad y con sus gestores, y se hace además con el estilo y objetivo de los Parerga ${ }^{27}$. No hay que olvidar que se encuentra en el último

«In Schopenhauer's case, Europe's encounter with oriental wisdom provided an opportunity for resolving the crisis in faith and morals that had been brewing since at least the seventeenth century. He viewed the Indian religions as having anticipated some of his own philosophical positions -idealism, atheism, pessimism and asceticism- and hoped they might fill the religious and spiritual vacuum opened by the decline of Church Christianity. Moreover, Schopenhauer did not regard the possibility of an oriental renaissance through Sanskrit as a betrayal of European culture in favour of an alien form of wisdom, but as the revival of the "old, true, profound, and original" religio-metaphysical Weltanschauung of the forefathers of modern Europe». Christopher Ryan, Schopenhauer's Philosophy of Religion. The Death of God and the Oriental Renaissance (Leuven: Peeters, 2010), 6-7. Élie Barnavi, op. cit., 12.

27 Una obra que, como señalaba Colli, «fu afferrata per se stessa, fu una scoperta, perché in essa per la prima volta un grande pensatore riusciva a comunicarsi e soltanto in seguito divenne un' introduzione alla più ardua costruzione, compressa, del Mondo. Anche ora, dopo un secolo, ritroviamo nei Parerga qualcosa di essenziale, che il Mondo non dà». Giorgio Colli, "Prefazione», en Arthur Schopenhauer, Parerga y paralipomena. Tomo primo (Milano: Adelphi Edizioni, 1981), 7. No hay que olvidar, como señala Zimmer en Arthur Schopenhauer. Ein philosophischer Weltbürger, que la obra fue casi desde el principio «catalogada» por la academia como un escrito menor, a la sombra de El mundo, sin embargo, ni el público ni una primera recensión del 17 de diciembre de 1851 la entendieron así, sino como una filosofía para el mundo que se adhería a una tradición filosófica concreta en la que se encontraban, por ejemplo: la eudaimonología de la filosofía clásica, Montaigne, Gracián, los moralistas franceses o los programas educativos de la Ilustración. Es decir, Parerga sería la segunda gran obra del autor, con su propia forma, contenido e hilo conductor. Y uno de sus rasgos más importantes era ser una obra de orientación para la vida, donde el individuo sí es importante; otro, era el modo de hacer y de concebir la filosofía (como sabiduría de vida, Lebenskunst, discurso no sistemático y enriquecido con las ciencias y la literatura). Aquí ya no se trata de superar el mundo, de negarlo, sino de cómo vivir en él: con los otros y con nuestra propia naturaleza. Y esta vía no hay que olvidar tampoco que ya está presente en los Manuscritos de los años 20. 
texto de Schopenhauer y que constituye, en ese sentido, un documento final sobre su filosofía de la religión que, como abordaré más tarde, se relaciona con una filosofía como arte de vivir.

\subsection{Las convicciones son sagradas / Lo único sagrado es la verdad}

Demófeles, «el amigo del pueblo», inicia el diálogo con un reproche a su viejo amigo Filaletes: que no alarde de su espíritu filosófico mofándose de la religión, porque la fe de cada cual es digna de respeto y, por ello, sagrada. A lo que Filaletes, «el amigo de la verdad», responde con su única convicción sagrada expresada en un lema: «hágase la verdad aunque perezca el mundo» ${ }^{28}$. Y puntualiza una idea que hoy suele olvidarse en el diálogo interreligioso: el respeto a las personas no nos obliga a compartir sus ideas o creencias, ni a autocensurarnos en nuestro uso de la razón y, menos aún, a transigir con el error, el atropello o la mentira.

\subsection{Las necesidades de la masa / La necesidad de investigar y pensar}

Para Demófeles, la necesidad metafísica, una necesidad universal, tiene una doble vertiente: teórica y práctica. Aspiramos a comprender el enigma de la existencia y necesitamos una guía para la acción. Pero la respuesta se dirige no al intelecto, sino al miedo y a la esperanza de los mortales. El amigo del pueblo es bastante pesimista sobre las capacidades del género humano y le reprocha a Filaletes, en más de una ocasión, su gran desconocimiento del abismo que nos separa a unos de otros ${ }^{29}$ y de lo que en realidad es el hombre. Según Demófeles, buen psicólogo y sociólogo, la respuesta a la necesidad metafísica debe adaptarse a la diversidad humana y habría dos tipos de hombres: el pueblo y la élite. La filosofía es solo para esta última. Los dos caminos no pueden ser transitados por todos, aunque ambos han evitado el 
horror vacui y han sacado a la humanidad de una existencia plana. La mayoría de la humanidad posee un nivel intelectual mediocre y una escasa formación. O no tiene tiempo, ni paciencia, ni fuerza para dedicarse a reflexionar. O prefiere no pensar y es poco receptiva a las razones. Está más inclinada a seguir a otros: a obedecer y a reconocer autoridades. Pero la pobreza no es un factor menor: la vida diaria convertida en supervivencia no deja tiempo para reflexionar y ni siquiera nos permite ser autónomos. Por eso, para la inmensa mayoría de la humanidad, por unas u otras razones, la vía corta para satisfacer la necesidad metafísica sería la religión. Es un bálsamo que nos ofrece tranquilidad y consuelo. Sitúa las tribulaciones de la finitud en un marco significativo en el que todo hombre, sea cual sea su condición y formación, puede reconocerse. Las distintas religiones son en realidad variaciones de un mismo esquema: representar la verdad edulcorada y de una forma intuitiva y plástica, adecuada a las masas ${ }^{30}$. De ahí la importancia de los mitos y las alegorías como vehículo. La verdad diluida es más pedagógica y más fácil de aceptar, y es accesible y significativa para todos los intelectos. Por ello, no es conveniente revolver en la «trastienda» de la religión.

Filaletes no niega la necesidad metafísica, pero combate su manipulación por parte de las religiones. El problema no es solo que estas no sean verdaderas. Han pretendido que la única metafísica válida sea la construida a medida del pueblo. Y la filosofía ha sido obligada a no salirse de este marco de referencia. Se ha establecido así una especie de pensamiento único paralizando toda investigación ${ }^{31}$, incluida la investigación sobre la misma religión. Filaletes exige directamente la madurez de la humanidad, que opte solo por la verdad, a cualquier precio. El conocimiento llegará a todos y mejorará a la humanidad, y esta -ya ilustrada- será capaz de tragar la verdad sin paliativos. La religión está condenada a desaparecer: el cristianismo del XIX es ya un moribundo que se 
mantiene vivo artificialmente ${ }^{32}$. El continuo progreso de las ciencias acabará minando la poca salud de la que aún goza. Pero la filosofía, no la ciencia, ocupará su lugar.

\subsection{Elegimos nuestras convicciones / Nos imponen una segunda naturaleza}

Para Demófeles, estaríamos ante dos tipos de convicciones (religiosas o filosóficas) y cada cual elige simplemente unas u otras. Para Filaletes, las convicciones han de analizarse y desde luego no todas valen lo mismo. Las religiosas son especiales ${ }^{33}$ : se inculcan en la infancia, cuando somos absolutamente moldeables. Se graban por adoctrinamiento y hábito, y se gestionan con la obediencia y el miedo. Se presentan como dogmas blindados por la revelación, custodiados y gestionados por una casta también intocable. La fe religiosa, una mezcla de dogmas y miedo, se inocula ${ }^{34}$. El Diccionario define «inocular» como introducir en un organismo una sustancia que contiene los gérmenes de una enfermedad. Es también contaminar a alguien con una falsa doctrina. Y es sinónimo de vacunación, en este caso contra el pensamiento autónomo ${ }^{35}$.

Filaletes recurre a la Historia para recordar que la religión ha sido un ejemplo de intolerancia, crueldad y exclusión, como prueban las inquisiciones, guerras de religión, cruzadas, hogueras, la matanza de las poblaciones indígenas de América, la posterior introducción de esclavos negros, etc. Y si ha hecho uso de la palabra o de la pluma, ha sido para mejor imponerse. Ha obligado a todos, creyentes o no. La religión ha estado vinculada a la violencia física y psíquica. Su monopolio de las mentes acaba dando sus frutos: nos crea una segunda naturaleza, como si crease nuevas circunvoluciones por

\footnotetext{
Ibíd., 359. (W X, 382).

Ibíd., 341. (W X, 361).

Ibíd., 342. (W X, 362).

Aquí está anticipado el espíritu del sacerdote que Nietzsche desarrollará en La genealogía de la moral, en donde analizará cómo este, un tipo humano o una forma de vida y no tanto una figura histórica, lleva a cabo una transvaloración de los valores mediante la que cura (da sentido) a la vez que enferma al individuo, y cómo el ideal ascético, en manos del sacerdote, ha hecho del hombre un ser malogrado y enfermo.
} 
las que irremediablemente han de discurrir todos los datos ${ }^{36}$. Esta segunda naturaleza bloquea la libre actividad afectiva e intelectual y falsea todo el saber humano. Las convicciones religiosas no son meras ideas erróneas ni creencias inocentes, porque modifican nuestra identidad, y perforan y violentan nuestra naturaleza. Habrá pocos espíritus fuertes para pensar después por sí mismos y desprenderse no sólo de los contenidos sino de sus esquemas mentales.

2.4 La religión como excipiente o base / La religión como peligrosa mezcla de verdad y mentira

Para Demófeles la religión no solo no está en contradicción con la verdad, sino que es una fuente de esta. Los mitos y narraciones de las religiones son, respecto a ella, como el excipiente en medicina o como una base en química. El excipiente es una sustancia inerte que se mezcla con el medicamento para darle las cualidades que faciliten su dosificación y uso. Del mismo modo, hay sustancias químicas que son gaseiformes y que para darles el uso deseado han de ser unidas a una base sólida palpable ${ }^{37}$. Incluso los filósofos han recurrido al mito para exponer su pensamiento. Pero para Filaletes no se puede tolerar nunca esa mezcla de verdad y mentira, pues una mentira piadosa es mentira al fin y al cabo y un instrumento de manipulación. La religión tiene que mostrar claramente que no es verdadera en sentido estricto. Sin embargo, despojarla de ese excipiente o base retórica, y por ello artística y afectiva, supondría privarla entonces de su fuerza; más aún: destruir su propia condición de posibilidad. Exigir la verdad desnuda, como insiste Filaletes, es como querer transportar agua sin un recipiente que la contenga.

Demófeles puntualiza que la religión sí que deja claro su estatuto: en el misterio, término técnico para la alegoría religiosa. El misterio es un dogma claramente absurdo, que alberga una verdad profunda. Es el envoltorio a través del que captamos esa verdad y satisfacemos

37 Ibíd., 347-348. (W X, 368-369). 
así la exigencia de sentido. Pero no dejaríamos de ser conscientes de la diferencia entre contenido y envoltorio, y nadie se quedaría en este. En cualquier caso, el sabio y el hombre preparado siempre pueden, en privado, desmontar el mito. Pero han de ser responsables en público: antes de arrebatarle al pueblo sus creencias deben ofrecerle unas de recambio. A Demófeles le preocupa tanto la perplejidad de las masas y lo que hoy llamaríamos «crisis de valores» o incluso «nihilismo» que, a veces, parece deslizarse hacia la censura.

2.5 Las ilusiones de la filosofía / La responsabilidad de la filosofía

Las pretensiones de la filosofía también se cuestionan. Schopenhauer, a través de Demófeles, recuerda el tópico que la identifica con una especulación ociosa ${ }^{38}$. Más que Filosofía, habría filosofías que dependen de las épocas y de individuos. Ninguna de ellas puede decir que haya alcanzado la Verdad. Esta ni siquiera es un camino recto, sino un espacio siempre en construcción y con contornos cambiantes, y muy pocos estarían dispuestos a vivir en una incertidumbre permanente. Incluso en el supuesto de que se alcanzase la Verdad, también pocos la comprenderían o podrían soportarla. Siempre haría falta, pues, la vía religiosa. Además en filosofía, como en religión, hay gradaciones, se podría distinguir en la metafísica filosófica una para la plebe de los filósofos y otra para su élite. La filosofía tiene también sus autoridades y sus credos. Es más: la fe y la autoridad en sí mismas no son necesariamente síntomas de debilidad o de inmadurez, ni son ajenas a la verdad: creemos y nos apoyamos en lo que otros han dicho y han hecho. No alcanzamos todo por nosotros mismos y no sometemos todo a escrutinio. La cultura, el progreso y la autonomía son posibles gracias también a estos actos de fe, a la tradición y a la autoridad.

En el caso de Filaletes, siempre será al menos posible una filosofía verdadera, porque su esencia es ya aspirar a la verdad y con ello a

38 «Lo que tenéis son simplemente sistemas metafísicos en los que nada es cierto más que los quebraderos de cabeza que cuestan». Ibíd., 357. (W X, 379). 
la emancipación de la humanidad. Filaletes llega a reconocer a la religión ciertos servicios prestados, pues la humanidad ha necesitado andadores y sucedáneos. Pero llegará un tiempo en el que la filosofía sustituya al mal necesario que ha sido la religión. A esta le augura no la derrota, sino la eutanasia, la buena muerte.

\subsection{Un estandarte público / Un conjunto de mentiras}

Según Demófeles, el debate sobre la religión no estaría bien planteado en términos de verdad o mentira. No importa que las religiones no se sostengan como teorías sobre el mundo o el hombre, porque no lo son. Lo que importa es su efecto práctico. Las religiones crean y aseguran las condiciones que garantizan el orden social y la coexistencia, pues frenan los bajos instintos y orientan a cada cual en la vida. Y como además es iluso esperar que toda la humanidad sea ilustrada, actúe de forma perfectamente racional y encuentre en ello una respuesta de sentido, es de extrema importancia que la religión sea preservada como un bien cultural absolutamente valioso y que cada pueblo se identifique con alguna. La religión es un conjunto de hipótesis útiles, verdaderas a nivel práctico: «como dijo Kant, tiene que haber un estandarte público del derecho y la virtud, y ha de ondear siempre alto. Al final da lo mismo qué heráldicas se encuentren en él, siempre y cuando indiquen lo que se quiere decir» ${ }^{39}$. Y la filosofía sólo puede venir después y apoyarse en el trabajo civilizador ${ }^{40}$ de la religión. La búsqueda de la verdad ha de ser, ante todo, búsqueda de verdades para la vida. Y en eso la religión es muy superior a lo que nos ofrece la filosofía.

Filaletes no reconoce los peligros que vislumbra Demófeles: desorientación, vacío, nihilismo. Todo lo contrario. Para quien busca la verdad, el camino y la liberación son en sí mismos ya un consuelo y, en esa medida, una forma también de responder a la necesidad metafísica. Su actitud es -en este sentido- similar a la kantiana en el Prólogo a la Primera edición de la Crítica de la razón pura: el

40 «el único medio de conducir, sujetar y aplacar a esa raza de animales dotados de razón, cuyo parentesco con el mono no excluye que lo tenga con el tigre». Ibíd., 355. (W X, 377). 
deber de la filosofía es también desilusionador al desprendernos de queridos errores.

\subsection{La identidad de individuos y sociedades / El fin de la fundamentación religiosa}

Otro inestimable servicio de la religión es ser el elemento que confiere identidad a individuos y a sociedades. Schopenhauer, por medio de Demófeles, pone sobre la mesa temas que hoy son de actualidad. Los pueblos se identifican y diferencian por su religión y no por otros rasgos de su cultura. Europa misma sería el resultado de una alianza religiosa, un club cristiano. Por eso Turquía, pese a su posición geográfica, no puede formar parte de la idea de Europa. Incluso en esta, si la unión se basa sólo en la política, siempre será débil. El universalismo que exporta también remite a ese mismo origen religioso como trasfondo. Es decir, la religión sería la identidad última de los Estados, de los ideales y de las instituciones supranacionales de Occidente. En ella está el origen de los valores que creemos nacidos laicos. La religión es, pues, mucho más que rezos y cuentos. Sigue siendo una potente fuente de legitimidad y de identidad para las que aún no tenemos recambio ${ }^{41}$.

En el caso de Filaletes se rechaza cualquier simbiosis entre religión y política. La religión como fundamento del derecho y del Estado, un argumento que Filaletes reconoce en boga, es solamente uno de los últimos apoyos con los que aquella intenta sobrevivir recurriendo al miedo, pues agita el fantasma del caos y la barbarie. Pero una rápida mirada al mundo clásico lo desmonta: no tenían sagradas escrituras, ni dogmas, ni la moral era predicada por los sacerdotes. Ni siquiera poseían una teoría concluyente sobre la naturaleza del

41 Según Huntington, en el mundo de la posguerra fría, las distinciones más importantes entre los pueblos no son ideológicas, políticas o económicas: son culturales. Sabemos quiénes somos cuando sabemos quiénes no somos, y con frecuencia sólo cuando sabemos contra quiénes estamos. Pero de todos los elementos que caracterizan a las civilizaciones, el más importante sería la religión. Esta habría tomado el relevo a la ideología, y el nacionalismo religioso al laico. Y recoge la afirmación de Régis Debray: «la religión no es el opio del pueblo, sino las vitaminas de los débiles». Samuel P. Huntington, El choque de civilizaciones y la reconfiguración del orden mundial (Barcelona: Paidós, 2005). 
alma o la vida después de la muerte. Y no por ello vivían en la anarquía, como bien muestra su extraordinaria herencia cultural de la que aún nos beneficiamos. Desde esta perspectiva Schopenhauer defiende a través de Filaletes una moral cívica. La razón y el aparato estatal con sus leyes y policía son, pues, suficientes para garantizar el orden social.

2.8 El estímulo de la moral y la ampliación de los valores occidentales/ El estímulo contra la moral

Pero las religiones cumplirían aún otra importante función: despertar la naturaleza moral del hombre y fomentar ciertos valores. Ni siquiera Platón, el filósofo antiguo más cercano a la trascendencia, habría ido más allá de la justicia. La antigua virtud, centrada en el bien común, tenía un alcance limitado y era un egoísmo bienintencionado $^{42}$. Occidente debiera mostrar su agradecimiento al cristianismo, esta religión que vino de Oriente y por la que la humanidad conoció la trascendencia e ideales más altos que el bien común (el amor al prójimo, la compasión, la caridad, la renuncia, la humildad). Aprendió la purificación por el sufrimiento, que la vida no puede ser un fin en sí misma y que está llamada a ser trascendida. Demófeles considera un beneficio la aparición de este ideal, la seriedad de la vida $^{43}$. El cristianismo habría sido una fuerza civilizadora en otro sentido: supo conservar la herencia clásica y fue el dique que contuvo las invasiones bárbaras y luego las civilizó.

Como cabe esperar, la posición de Filaletes es bien distinta. La excelencia del ideal humano de la Antigüedad se habría malogrado por el triunfo del cristianismo en la Edad Media. La religión moribunda intenta ahora apropiarse de la moral y presentarse como su origen y garantía, pero el fundamento de la moral no está ni en religiones ni en filosofías. Sin una naturaleza buena, la religión apenas puede

42 Arthur Schopenhauer, «Sobre la religión», op. cit., 361. (W, X, 384).

43 La cosmovisión que luego criticará tanto Nietzsche y a la que opondrá, no desde luego la frivolidad, sino la jovialidad (Heiterkeit) inspirada en el pesimismo griego o de la fortaleza, identificado con el ideal de tragedia clásica. 
nada ${ }^{44}$. Para Filaletes, como para Schopenhauer, la compasión es el motor de la moral y el único fundamento para la ética. Puede que el cristianismo sea portador de un profundo sentido moral, pero un vistazo a la Historia causa estupor e impide afirmar que haya mejorado a la humanidad. Pero Filaletes va más allá: los dogmas religiosos socavan la conciencia moral e incluso malogran todo sentimiento de compasión y humanidad. La adulación a la divinidad, los ritos y ofrendas acaban sustituyendo a las buenas acciones y dispensándonos del deber hacia los demás. La moralidad se sustituye por:

sacrificios de animales en el templo, encargo de misas, edificación de capillas o cruces en los caminos (...) de modo que hasta los más imperdonables crímenes son expiados con ellas, como también con la penitencia, el sometimiento a la autoridad sacerdotal, la confesión (...) con lo cual en último término los sacerdotes aparecen casi exclusivamente como intermediarios del comercio con los dioses sobornables ${ }^{45}$.

El creyente se limita -en el mejor de los casos- a la indiferencia o a manifestar que las creencias del otro no concuerdan con las suyas, la única Verdad. En el peor, se siente autorizado - por amor a Dios-a aplastar a los que no compartan su fe. El lema «Dios lo quiere» ha permitido justificar todos los atropellos del cristianismo ${ }^{46}$. Los cerebros embotados por el adoctrinamiento nada tendrán que decir ante un posible diálogo interreligioso. El creyente es, paradójicamente, el menos indicado para el diálogo. La cerrazón y el fanatismo parecen ser males congénitos en quienes optan por la vía de las convicciones religiosas. El peor puesto lo ocuparía el judaísmo. Filaletes es muy duro con él ${ }^{47}$. La herencia judía habría malogrado al cristianismo, por ejemplo respecto a la consideración de los animales y de la naturaleza

44 «Imagínate que de repente se declarasen abolidas todas las leyes criminales (...) entonces creo que ni tú ni yo tendríamos el valor de ir ni siquiera de aquí a casa bajo la protección de los motivos religiosos». Ibíd., 367. (W X, 391).

45 Ibíd., 367-368. (W X, 391-392).

46 Ibíd., 369. (W X, 393). En nuestra época ha cobrado fuerza otro muy similar, basado en la misma confusión y atropello: «Dios es grande» (Allahu akbar). También manipula el sentimiento religioso, secuestra una religión y justifica lo injustificable. Pero Filaletes no entra en estas distinciones.

47 Respecto al judaísmo afirma el autor en nota: «iOjalá todos los pueblos con un Dios que hace de los países vecinos 'Tierra de promisión' encuentre a su debido tiempo su Nabucodonosor y su Antíoco Epifanes, y no se tengan cumplidos con él!». Ibíd., 371. (W X, 395). La opinión de Schopenhauer es también muy negativa respecto al islam, al que entiende como una deriva del judaísmo, si bien aprecia su mística. 
en general, a los que es lícito explotar sin límites. Pero el problema de fondo sería la intrínseca intolerancia que implica el monoteísmo en sí. El judaísmo, que sería su origen, es por ello una religión excluyente, identitaria y liderada por un Dios guerrero. Schopenhauer, a través de Filaletes, llega a decir:

después de que en Egipto, por mandato expreso de Jehová, hubo robado a sus antiguos y confiados amigos los vasos de oro y plata que le habían prestado, con el asesino Moisés a la cabeza emprendió su expedición de asesinato y pillaje en dirección a la Tierra Prometida; ello, con el propósito de arrebatar aquella "Tierra de Promisión" a sus legítimos ocupantes, siguiendo el mandato expreso y reiterado del mismo Jehová de no conocer la compasión y asesinando y extinguiendo sin piedad a todos los habitantes, incluidos mujeres y niños (...) porque no estaban circuncidados y no conocían a Jehová, razón suficiente para justificar cualquier horror contra ellos ${ }^{48}$.

El politeísmo sería constitutivamente tolerante, pues «los dioses (...) viven y dejan vivir: ante todo soportan bien a sus colegas, los dioses de la misma religión y esa tolerancia se extiende después a los dioses extraños ${ }^{49}$. El hinduismo y el budismo tampoco habrían promovido la violencia ${ }^{50}$, pero Schopenhauer aquí reconoce que estas religiones no están exentas de problemas. Y que aunque no nos han llegado casi noticias de intolerancia, guerras o violencia en ellas, quizá se deba a la falta de información sobre sus países de implantación.

\section{La necesidad metafísica y la sabiduría trágica}

\subsection{Los rostros de Jano: un encuentro en tablas}

¿Cómo acaba entonces el diálogo? Demófeles es mucho más cauto respecto a los grandes ideales ilustrados o las ilusiones de la propia filosofía. Apuesta por verdades útiles para la vida. Es pesimista acerca de la naturaleza, la diversidad y el futuro de la humanidad. Pero también es muy consciente del impacto de las condiciones

Ibíd., 369-370. (W X, 394).

Ibíd., 371. (W X, 396).

Ibíd., 371. (W X, 395).

Universidad de San Buenaventura, Bogotá • Facultades de Filosofía y Teología 
materiales, pues malogran la vida de millones y degradan también espiritualmente. En ese sentido, se muestra más flexible e indulgente. A través de él, Schopenhauer suscribe la necesidad de la «mentira» y la ilusión: dispensan eficazmente contenidos para asegurar la paz social y el equilibrio psíquico. Es consciente de la debilidad teórica de las religiones y reconoce las tropelías realizadas en nombre de la religión, pero también distingue entre el valor de un ideal y su concreción. Muestra su preferencia por el cristianismo como ideal ético y civilizador, aunque es partidario de proteger la religión en general como patrimonio de la humanidad. Demófeles plantea también cuestiones de fondo de primera magnitud: la ausencia de un recambio comparable a la religión como fundamento universal de los valores; los peligros del nihilismo; la reducción de la identidad de los pueblos a un solo elemento, la religión. La religión se nos muestra como un valioso patrimonio de la humanidad. Aglutina factores de gran efecto y que en ningún otro producto cultural encontramos juntos: gran comprensibilidad unida a una cierta oscuridad e impenetrabilidad; una moral justa y suficiente; una fuente permanente de consuelo; el apoyo en una autoridad que ha perdurado en el tiempo, reconocimiento general, documentos o tradiciones que recogen la memoria de los pueblos, incluso un tono solemne y efectivo en la expresión de su rito. Esta conjunción es capaz de congregar a los hombres y satisfacer tantas y tan importantes necesidades, que ha de ser protegida. Más aún: es «el tesoro más sagrado de cualquier pueblo» ${ }^{51}$. La religión es un fenómeno muy complejo. No podemos hablar de ella como algo unívoco ni de forma abstracta. Ni es sólo una cuestión de preparación, capacidad o ilustración, una simple fase evolutiva a superar. Como opción vital y necesidad de sentido no tiene que ver con el nivel intelectual ni con el progreso. Los interrogantes de Demófeles tienen hoy más lecturas y recorrido: por ejemplo, cuál es el futuro de los países que se identifican con confesiones religiosas, si pueden acoger una sociedad plural; o cómo concertar lo público y

51 Ibíd., 353. (W X, 375). 
lo privado en cuestiones de religión cuando en nombre de la libertad, reducida a laicidad, se impone la invisibilidad religiosa del creyente o del creyente de ciertas confesiones, etc.

La posición de Filaletes sobre la religión es mucho más plana y sesgada, y reduce el fenómeno religioso a cierto cristianismo. Filaletes ha jurado fidelidad absoluta a la bandera de la verdad sin preocuparse por el éxito ${ }^{52}$ ni por los costes. La Verdad del filósofo ha de ser la misma para todos y exigible a todos, por lo que en algunos momentos parece dogmático. La verdad sólo es patrimonio de la filosofía ${ }^{53}$, algo que ni la propia filosofía se atrevería a sostener. Por otro lado, como Schopenhauer, no sitúa el fundamento de la moral ni en la religión ni en la filosofía, sino en la compasión, lo cual ciertamente aboga por la búsqueda de valores universales fundados en la naturaleza humana. En el diálogo muestra interés por los estudios comparativos entre culturas. Pero también apunta más allá del análisis del propio Schopenhauer, cuando al final del diálogo reclama algo muy importante: una investigación sobre la religión mucho más profunda, donde la historia y la psicología habrían de tener un papel predominante ${ }^{54}$. Y este será el camino que emprenda Nietzsche sobre todo en La genealogía ${ }^{55}$. En este sentido el debate queda abierto, pero el diálogo entre Demófeles y Filaletes acaba en tablas: la filosofía y la religión han de seguir cada una su camino sin interferencias mutuas. La religión es un fenómeno complejo y su doble rostro, benéfico y tenebroso, es lo que alternativamente afirman haber

52 Ibíd., 356. (W, X, 378).

53 «...tendré que volver a oír que mi filosofía es desconsoladora, precisamente porque hablo de acuerdo con la verdad, pero la gente quiere oír que Dios el Señor lo ha hecho todo bien. Id a la iglesia entonces y dejad a los filósofos en paz. O por lo menos no pretendáis que adapten sus teorías a vuestro adiestramiento: eso hacen los granujas, los filosofastros: a ellos podéis encargarles las teorías a vuestro gusto». Arthur Schopenhauer, «Adiciones a la teoría del sufrimiento del mundo», en Parerga y Paralipómena II, op. cit., 316. (W, IX, 326).

54 Arthur Schopenhauer, "Sobre la religión", op. cit., 365. (W X, 388-389).

55 Por ejemplo, el plan de La genealogía de la moral en Ecce homo: «La verdad del primer tratado es la psicología del cristianismo (...). El segundo tratado ofrece la psicología de la conciencia (...). El tercer tratado da respuesta a la pregunta de dónde procede el enorme poder del ideal ascético, del ideal sacerdotal (...). Tres decisivos trabajos preliminares de un psicólogo para una transvaloración de todos los valores». Friedrich Nietzsche, Ecce homo. Cómo se llega a ser lo que se es (Madrid: Alianza Editorial, 1994), 109-110. (KSA VI, 352-353). 
puesto de relieve entre los dos amigos. Cabe entonces preguntarse por la posición final de Schopenhauer: si acaba en tablas como sus personajes y cuál es la relación del diálogo con el resto de su filosofía. Y una cuestión de fondo: si solo se satisface la necesidad metafísica mediante la religión o la filosofía y si esto implica la negación de la voluntad. A esto me voy a referir en lo que resta.

\subsection{Los vasos sagrados y la metafísica natural}

En el capítulo de los Complementos dedicado a la necesidad metafísica, Schopenhauer se había referido ya, aunque con menos detalle, a la religión y a la filosofía como dos vías muy distintas para responder a la necesidad metafísica. Podríamos decir, entonces, que la posición del autor respecto a esta viene ahora representada por los dos personajes. Pero al ser Filaletes el filósofo, cabría pensar que Schopenhauer se identificaría con el personaje. Este no especifica los contenidos de su filosofía, aunque se deduce que, pese a su actitud ilustrada, la verdad que aguardaría al género humano es desilusionadora y difícil de digerir. Por suerte, encontramos al personaje en otro texto de Parerga y Paralipómena, al final de «Sobre la teoría del carácter indestructible de nuestro verdadero ser con la muerte». Allí, en el breve encuentro con el sofista Trasímaco, tenemos ocasión de comprobar que las líneas fundamentales de su filosofía son las de Schopenhauer. El ingenuo Filaletes le explica al sofista que, en cuanto fenómeno, estamos destinados a desaparecer, pero al ser nuestra esencia voluntad somos partícipes de una suerte de inmortalidad, pues la voluntad es eterna. Filaletes no llega a exponer nada más; basta esta explicación metafísica para que Trasímaco le responda airado: «Pueril y extremadamente ridículo eres tú y todos los filósofos; y sería solo por diversión y pasatiempo por lo que un hombre serio como yo trabase relaciones con esa clase de chiflados durante un cuarto de hora. Ahora tengo cosas más importantes que hacer: iCon Dios! ${ }^{56}$. El suceso es, sin embargo, significativo y ante

56 Arthur Schopenhauer, «Sobre la teoría del carácter indestructible de nuestro verdadero ser con la muerte», en Parerga y Paralipómena II, op. cit., 297. (W X, 306). 
todo aleccionador para el propio Filaletes. Trasímaco es el individuo instalado en el mundo fenoménico y no desea más respuesta ni más trascendencia que cuidar su vida y solventar sus asuntos. La necesidad metafísica parece no ser tan universal. O si lo queremos: la religión y la filosofía no son las únicas fuentes en las que un individuo encuentra sentido. Y algo más desalentador: la filosofía tiene poco predicamento. Desde luego no motiva al hombre medio a emprender, sin más, una consideración más profunda sobre la existencia ni a buscar la verdad a toda costa. Las diferencias de actitud ante la existencia son, efectivamente, abismales.

Pero tenemos que volver al diálogo, porque pasa casi desapercibida una importante afirmación de Filaletes que transforma por completo su posición y su filosofía. Hay un momento en que se desmarca de su guión como defensor de la verdad absoluta y, superando al propio Schopenhauer -y esto es importante-, indica un camino no solo ajeno a la «seguridad» de la religión, sino completamente diverso al de cualquier filosofía con pretensiones hegemónicas. De hecho, le responde así a Demófeles: «no engañes a nadie, antes bien, confiesa no saber lo que no sabes y deja a cada cual que se cree sus propios dogmas $»^{57}$. La variedad resultante no nos dará ninguna verdad absoluta, ninguna seguridad, pero la confrontación abrirá un nuevo espacio: el de la tolerancia ${ }^{58}$. Y en esto deposita la esperanza: al menos todos debatirán entre sí e incluso se rectificarán unos a otros. Demófeles se mofa porque entiende esto como la fundación por parte de cada cual de su religión. Pero Filaletes lo que está defendiendo es una nueva actitud y un nuevo espacio «sagrado» asociados a la pluralidad. En este serían posibles muchas versiones, religiosas o no, filosóficas o no, de la necesidad metafísica. Pero entonces, esta se habría transformado más bien en un cierto arte de vivir que exige -ante todo- respuestas más personales y no necesariamente caracterizadas por credos o sistemas filosóficos, ni por dualismos, ni por la

57 Arthur Schopenhauer, «Sobre la religión», op. cit., 357. (W, X, 379-380).

58 Ibíd., 357. (W, X, 380). 
seriedad de la vida, ni por la renuncia... Schopenhauer va aquí más allá de su propuesta filosófica fundamental: más allá de la negación del mundo, es decir, más allá del libro IV de El mundo como voluntad y representación. Y hay que señalar también otro aspecto más obvio en esa misma dirección. Aunque Demófeles suscribe una religión pesimista y Filaletes al menos las líneas generales de la filosofía de Schopenhauer, el diálogo no se ocupa de la negación de la voluntad ni promueve lo que el autor llama en El mundo como voluntad y representación "una tendencia anticósmica», es decir, ascética. Los argumentos de los personajes inciden en la búsqueda de sentido, pero para seguir viviendo en sociedad: controlada, menor de edad, ilusa pero reconfortada, en el caso de Demófeles; e ilustrada, fuerte, emancipada y desencantada en el de Filaletes, para quien el proceso mismo de buscar la verdad es ya valioso y generador de sentido.

En la parte final del texto «Sobre la religión», después del diálogo entre los dos amigos, Schopenhauer toma la palabra para continuar con la temática. Y afirma que todo pensamiento especialmente iluminador sobre el significado de la existencia tiene para la inmensa mayoría de los hombres el mismo efecto que un mensaje divino, como si de un verdadero oráculo se tratase: es para ellos una revelación. El estamento religioso se habría apropiado de estos pensamientos especiales presentándolos como mensajes de la divinidad ${ }^{59}$, privándoles de su origen humano, divinizándolos, y convirtiéndose ellos, de paso, en los portavoces y albaceas de lo divino. Schopenhauer también se refiere de nuevo al aspecto alegórico de las religiones, pero no rechaza la alegoría en sí misma, sino la confusión de planos y lenguajes y las filosofías teñidas de religión y las religiones que se presentan como filosofías. El blanco de sus críticas es el teísmo judeo-cristiano y la manipulación de la necesidad de sentido. Apunta por el sentimiento de ese mal apenas podrá por menos de irritarse con aquellos que alegan poseer noticias especiales al respecto, las cuales nos quieren comunicar bajo el nombre de revelaciones». Ibíd., 374. (W, X, 398-399). 
también a las mutaciones de las religiones, en este caso, a las del cristianismo agonizante. Mientras que antes estaba bien situado en las altas esferas, relacionado con la política, ahora se refugia en las bajas donde se presenta en forma de «conventículos» ${ }^{60}$. No especifica cuáles son sus nuevas formas de expresión, si hay, por ejemplo, algún peligro de sectarismo o qué ocurre cuando la religión se alía con la ignorancia y el descontento de los más desfavorecidos. Hay que subrayar también que Schopenhauer no opta por un racionalismo a ultranza. Por eso responde con ironía a propósito de la consecución de la Verdad: «Es una pena que no hayamos empezado antes: pues entonces estaríamos ya allíı ${ }^{61}$. Y se pregunta, pero de forma retórica, si sería posible explicarle al hombre corriente las tesis de su filosofía. Con esta doble consideración se diferencia de la actitud de Filaletes. Acaba concediendo que la filosofía y la religión han de coexistir, aunque necesariamente separadas. Y cada cual tiene que optar entre creer y filosofar ${ }^{62}$. No es posible sentarse entre dos sillas o «servir a dos señores a la vez».

Pero entonces, ¿̇qué? ¿̇Solo nos queda ser masa, puesto que los filósofos pertenecen a una rara élite? Nuestro destino sería el adocenamiento. Mientras los privilegiados tendrán que estar dispuestos a vivir como nómadas intelectuales. Pero aquí no acaba la reflexión del autor. Schopenhauer se refiere también a algo distinto a las religiones y a las filosofías: un fondo sapiencial de la humanidad que no es ajeno a su definición de «revelación». Y aquí está lo más significativo de su posición. Habría, pues, una sabiduría o metafísica natural que acompaña, de forma más o menos explícita, a la humanidad: la necesidad de ser redimidos de la existencia y el camino para hacerlo, una tendencia ascética que Schopenhauer llama «negación de la voluntad». Esa enseñanza fundamental, o legado perenne, habría sido malograda por el componente judío del cristianismo, el cual habría por ello difi-

62 «La fe y el saber no se llevan bien en una misma mente: son como el lobo y el cordero en una misma jaula; y, por cierto, el saber es el lobo que amenaza devorar al vecino». Ibíd., 404. (W, X, 432). 
cultado también la convergencia, en lo fundamental, entre Oriente y Occidente. La filosofía, un saber que vierte en conceptos intuiciones fundamentales sobre la existencia y el mundo, tiene la tarea de mantener ese patrimonio universal en estado puro, desprendiéndolo una y otra vez de cualquier mezcla. Los dogmas y mitos:

han de verse como los vasos sagrados en los que esa verdad que es conocida y expresada desde hace milenios, quizá desde el comienzo de la humanidad, pero que en sí misma sigue siendo un misterio para la masa, se hace accesible a ella según la medida de sus fuerzas, se conserva y sigue transmitiendo a lo largo de los siglos (...) Tan pronto como el vaso se enfrenta a la destrucción debido al contacto con una época heterogénea, se hace necesario sustituirlo por otro a fin de salvar su sagrado contenido y conservarlo para la humanidad. Y, dado que aquel contenido es idéntico a la verdad misma, la filosofía tiene la misión de presentarlo puro y sin mezcla (...) para el escaso número de los que son capaces de pensar ${ }^{63}$.

Intuitivamente cada hombre sería consciente de las verdades filosóficas: pero llevarlas al saber abstracto o a la reflexión es la tarea de la filosofía, que ni puede ni debe hacer más. Ese legado de la humanidad permea culturas y épocas, son arcanos más allá de filosofías y de religiones concretas. Los vasos nos pueden despistar, pero son necesarios, pues sin recipientes (ya sean narraciones o conceptos), ese saber no es operativo.

Schopenhauer critica las misiones del cristianismo porque han despreciado el fondo sapiencial de otras culturas. Y augura una revalorización y un reencuentro ${ }^{64}$ más allá de las gramáticas. Da

63 Arthur Schopenhauer, El mundo como voluntad y representación. Complementos, op. cit., 686. (W IV, 737). 64 Christopher Ryan señala los efectos de este reflujo en la propia India. La consideración positiva y elogios de los pensadores occidentales contemporáneos habrían estimulado el interés de los jóvenes intelectuales indios hacia su propio legado: revitalización, estudios metafísicos más profundos, etc. Pero también habría sido la condición de posibilidad del movimiento Neo-Vedãnta influido por Vivekenanda: «Paul Hacker has charted the relation between Vivekananda's meeting and acquaintance with Schopenhauer's disciple Paul Deussen in September 1896, and the appearance of Schopenhauer's interpretation of tat tvan asi as the metaphysical basis of ethics in Vivekananda's subsequent works. Hacker has also shown how subsequent Neo-Vedãntins influenced by Vivekenanda's appropriation tender to consider the ethical interpretation of tat tvam asi as the traditional outlook of ancient Hinduism, oblivious to its original formulation in the works of a nineteenth-century German idealist. The Neo-Vedãntins's success in constructing a coherent and sophisticated Weltanschauung that was simultaneously Hindu, universal, and geared towards moral and social action, became an important ideological feature of Indian Nationalism. Sir Sarvepalli Randhkrishnan, the most prolific and probably most influential of the twentieth-century Neo-Vedãntins (...) also embodied its ideals during his presidency of independent India from 1962 to 1967». Christopher Ryan, op. cit., 231. 
igual cómo se relate ${ }^{65}$, y es irrelevante que se parta de una religión teísta o atea. Las pretensiones de la filosofía y las de la religión no se extinguen, pero quedan de algún modo desplazadas en función de esta concepción más amplia del saber. No hay, pues, un camino único, ni siquiera dentro del ámbito de la espiritualidad, para responder a la necesidad metafísica. Schopenhauer reconoce una sabiduría primigenia y difusa, común e intercultural, que nutre a las religiones y a las filosofías. Esa sabiduría apuesta por un segundo plano de la realidad que redima esta y por el valor de la trascendencia ${ }^{66}$, pero caben diversos relatos y la trascendencia -como ocurre en su filosofía- puede ser inmanente. En El mundo como voluntad y representación, la consideración profunda de la existencia nos lleva a una solución de la misma envergadura: la negación de la voluntad, pues la esencia de la realidad es un movimiento ciego y eterno y nada más. Nuestra felicidad se reduce a tener siempre algo que desear y esperar que transcurra poco tiempo entre un deseo y el siguiente: cuando el ritmo es lento o no existe, experimentamos dolor; cuando hay estancamiento, aburrimiento y hastío. La vida es «un negocio que no cubre los gastos» y la aspiración a la felicidad con la que aterrizamos en ella, un error innato del que más vale librarnos lo más pronto posible. El optimismo, que afirma que vivimos en el mejor de los mundos posibles, no es más que el producto de la ceguera o del cinismo. Ni siquiera la vida en sociedad es más reconfortante: de los demás, como de nosotros mismos, cabe esperar bien poco. Y si contemplamos la vida de nuestros compañeros de viaje, el espectáculo aún nos encoge más el corazón y hace saltar en pedazos la pregunta por el sentido. Los ejemplos que cita Schopenhauer no pueden ser más elocuentes. Pongamos por caso el topo:

65 «Con qué mitos y dogmas den cuenta a su razón de ese conocimiento intuitivo e inmediato, y de la transformación que experimentaron es, como se dijo, indiferente».Arthur Schopenhauer, El mundo como voluntad y representación, op. cit., 456. (W II, 487).

66 Como señala Christopher Ryan, la filosofía de la religión de Schopenhauer difiere de la de sus contemporáneos alemanes al combinar una fuerte oposición al monoteísmo y al concepto de Dios con una fuerte valoración de la ética cristiana. Christopher Ryan, op. cit., 222. 
cavar penosamente (...) constituye la ocupación de toda su vida: una noche perpetua lo rodea: sus ojos embrionarios los tiene solamente para huir de la luz (...) ¿ Pero qué consigue con esa vida esforzada y falta de alegría? Comida y apareamiento; o sea, nada más que los medios para proseguir el mismo camino y volver a emprenderlo en un nuevo individuo ${ }^{67}$.

Otro ejemplo lo refiere al botánico alemán Junghuhn:

en Java vio un campo inmenso lleno de esqueletos (...) de grandes tortugas (...) que para poner sus huevos salen del mar y andan ese camino; entonces son capturadas por perros salvajes que uniendo sus fuerzas les dan la vuelta, les arrancan la armadura inferior, o sea, el pequeño caparazón del abdomen, y las devoran vivas. A menudo sobre los perros se lanza entonces un tigre. Toda esa desolación se repite miles de veces, un año tras otro. ¿Para qué han nacido, pues, esas tortugas? ¿Por qué culpa tienen que sufrir ese tormento? ¿Para qué toda esa escena de crueldad? La única respuesta es: así se objetiva la voluntad de vivir ${ }^{68}$.

Este impulso ciego, la voluntad, no salva, ni redime, ni consuela, ni es bondadosa, ni es providente, ni crea el mundo para un fin, ni imparte justicia, etc. El sentido de la vida es formar parte del ciclo, alimentar el movimiento de la voluntad.

La objetivación más alta de esta, el hombre, es el único fenómeno que puede emprender la conversión, pues en él la voluntad tiene conciencia de sí. Schopenhauer señala varias vías que conducen a negarla: el arte, la santidad, la ascética, y lo que llama la »segunda vía». Las primeras son minoritarias y dependen de un conocimiento o lucidez especial. La última no depende del conocimiento, sino del sufrimiento padecido en primera persona, de los golpes de la vida que van minando la voluntad en nosotros. Y está abierta a todos, pues nadie es inmune al sufrimiento. «La cabalgadura más rápida» purifica y redime, porque alecciona, escarmienta: experimentamos sin tapujos el verdadero rostro de la existencia. Entonces reconocemos que lo mismo ocurre en el Todo y nos hacemos "genial en un sentido ético», de un modo similar al artista, que es capaz de ir de lo particular a la

67 Arthur Schopenhauer, El mundo como voluntad y representación. Complementos, op. cit., 399. (W III, 414).

68 Ibíd., 399-340. (W III, 415). 
esencia $^{69}$. Aunque a menudo solo ante la cercanía de la muerte y la ausencia de esperanza se produce un cambio tan radical.

\subsection{El valor del arte}

Frente a la negación de la voluntad, Trasímaco, que sería el prototipo del hombre corriente, está satisfecho con el mundo. Y Filaletes, deja abierto el camino a la pluralidad y al diálogo entre distintas opciones vitales. Y ni él ni Demófeles apuestan por la negación de la voluntad. Hay, pues, ejemplos que ponen en duda la identificación del pensamiento de Schopenhauer exclusivamente con la tesis de la negación de la voluntad. Incluso en El mundo como voluntad y representación se reconoce la posibilidad de un individuo que afirme la vida tal cual es ${ }^{70}$. Entonces, el sufrimiento y la muerte, que creaban y alimentaban la necesidad metafísica, no son en sí determinantes y cabe tanto la afirmación como la negación del mundo. De hecho, cada cual percibe un mundo distinto y, en esa medida, necesita una filosofía distinta ${ }^{71}$. Es más: Schopenhauer reconoce que a la filosofía no le incumbe prescribir ningún ideal de sentido. Pero incluso algunas de las vías de redención de las que habla el autor son también un camino para transitar hacia la afirmación del mundo una vez transformado. Por ejemplo: el hombre bueno, compasivo, encuentra sentido en la vida que ha elegido. Su comportamiento no depende de una religión ni de un sistema filosófico. Vive en comunión con todos los seres vivos. No solo no produce sufrimiento a los demás, sino que los alivia. Modera y modela su voluntad y opta por la transformación, y mejora y repara incansablemente el mundo fenoménico. $\mathrm{Su}$ actitud transmite una amplia fraternidad y pone en marcha una

«Pero enseguida nos seduce de nuevo el engaño del fenómeno, y sus motivos vuelven a poner en marcha la voluntad (...) Las tentaciones de la esperanza, los halagos del presente, la dulzura de los placeres, el bienestar que toca en suerte a nuestra persona (...) tira de nosotros y asegura de nuevo los lazos». Arthur Schopenhauer, El mundo como voluntad y representación, op. cit., 441. (W II, 470). «Un hombre que hubiera incorporado firmemente a su mentalidad las verdades expuestas hasta ahora (...) que encontrara satisfacción en la vida (...) y que al reflexionar tranquilamente deseara que su vida, tal y como la había experimentado hasta entonces, durara eternamente o retornara siempre (...) ese hombre se hallaría 'con fuertes y vigorosos huesos en la bien asentada y estable tierra' [Goethe, Límites de la humanidad] y no tendría nada que temer». Ibíd., 340. (W II, 357-358). 
ecología profunda aunque, como el héroe de la tragedia, sepa que al final será aniquilado.

Pero el caso más complejo es el del artista. El artista es ante todo el genio, el cual está dotado de un excedente de inteligencia que le permite abandonar la forma de conocimiento fenoménico, ligado al principio de razón suficiente y esclavo, por tanto, de la voluntad. Libre ya de esta emplea el excedente en la pura «visión contemplativa». El artista se aparta así de la corriente del devenir ${ }^{72}$. Mediante esta disociación, lo que percibe se convierte para él en representación pura, pues ya no es ningún motivo que excite su voluntad ${ }^{73}$. Esta representación es producto de una intuición especial: la estética, que transforma lo que se conoce y al que conoce. Ya no es individuo, sino sujeto puro, desinteresado: un ojo que contempla sin sentirse afectado, sin reaccionar. Y lo que capta no es la cosa individual, ni un concepto (objeto del pensamiento racional y de la ciencia), sino la Idea, el modelo en el sentido platónico ${ }^{74}$. La genialidad es perfecta objetividad: la dirección objetiva del espíritu, opuesta a la subjetiva que se encamina a la propia persona, a las necesidades egoístas, a la voluntad. Se desliga de la forma habitual de ver, de valorar y de relacionarse con el mundo: una forma fragmentaria y sesgada, pero sobre todo interesada y cosificadora. Genialidad es la capacidad de comportarse de forma puramente intuitiva, perderse en la intuición el tiempo necesario para reproducir

72 «No conoceríamos ya cosas individuales ni cambio ni pluralidad (...) y, por consiguiente, nuestro mundo sería un nunc stans (...) El tiempo es solamente la visión fragmentaria y disgregada que tiene un ser individual de las ideas, las cuales están fuera del tiempo y son, por lo tanto, eternas: por eso dice Platón que el tiempo es la imagen movida de la eternidad». Arthur Schopenhauer, El mundo como voluntad y representación, op. cit., 229-230. (W I, 228-229).

73 «No considera ya el dónde, cuándo, porqué y para qué de las cosas sino única y exclusivamente el qué; cuando su conciencia no se interesa tampoco por el pensamiento abstracto, por los conceptos de la razón, sino que, en lugar de todo eso, entrega a la intuición todo el poder de su espíritu, se sumerge totalmente en ella y llena toda su conciencia con la tranquila contemplación del objeto natural que en ese momento se presenta (...), se pierde completamente en ese objeto, es decir, olvida su individualidad, su voluntad, y queda únicamente como puro sujeto, como claro espejo del objeto de modo que es como si existiera el objeto sin nadie que lo percibiera y no se puede ya separar al que intuye de la intuición sino que ambos se han hecho una misma cosa, ya que toda la conciencia está llena y ocupada por una sola imagen intuitiva». Ibíd., 232-233. (W I, 231-232).

74 «...la cosa individual se convierte de un golpe en idea de su especie, y el individuo que intuye, en puro sujeto de conocimiento. El individuo como tal conoce solo cosas particulares; el sujeto puro de conocimiento, solamente ideas». Ibíd., 233. (W I, 233). 
lo captado, fijar lo que está suspendido en el fluctuante fenómeno. Ser un espejo del mundo: esta es la única cualidad espiritual que es capaz de producir auténticas obras de arte.

Esta capacidad puede activarse en la producción/contemplación de una obra de arte, pero también ante la naturaleza o ante sucesos impactantes de la vida. Pero en todos estos casos -y esto es lo importante- el individuo no tiene por qué negar el mundo. Más bien lo contrario: lo completa y relativiza. No se trata sólo de una forma de conocimiento, sino de una forma distinta de relacionarnos con lo que existe y una transformación y un cambio en la comprensión de la existencia, que redime todo al colocarlo bajo una óptica benéfica y liberadora. Es como un retiro temporal del mundo, pero para contemplarlo mejor y «dejarlo ser». Si el mundo es un gran teatro en el que todos tenemos la condición de actores y padecemos nuestro papel, el artista consigue asistir al espectáculo desde el patio de butacas. Y en tanto espectador es desinteresado, se «pierde» en la obra que se representa. Desde aquí, no padeciendo, sino viendo, puede «justificarla», en el sentido de asumirla, asimilarla, una vez transformada y él con ella.

El arte es, pues, un ejercicio metafísico y además es muy cercano a la religión. Por eso dice Schopenhauer:

No solo la filosofía, también las bellas artes trabajan en el fondo para resolver el problema de la existencia. Pues en todo espíritu que se entrega alguna vez a una consideración objetiva, por muy oculta e inconsciente que pueda ser, se ha activado una aspiración a captar la verdadera esencia de las cosas, de la vida y de la existencia (...) El resultado de toda captación puramente objetiva, es decir, artística, de las cosas, es una expresión más de la esencia de la vida y de la existencia, una respuesta más a la pregunta: '¿Qué es la vida'?'. A esa pregunta responde a su manera y con perfecta corrección cada obra de arte auténtica y lograda ${ }^{75}$.

La capacidad para el arte o para la filosofía «tiene una misma raíz, si bien es muy diferente en su orientación y en lo secundario» ${ }^{76}$. Las obras artísticas «contienen de manera reconocida un tesoro de pro-

Ibíd., 455. (W IV, 480). 
funda sabiduría: precisamente porque desde ellas habla la sabiduría de la propia naturaleza de las cosas $\rangle^{77}$. Quien se acerca a estas obras «ha de contribuir por sus propios medios a sacar a la luz aquella sabiduría: por consiguiente, solo capta lo que su capacidad e instrucción admiten; igual que en alta mar un barco solo puede lanzar su sonda hasta donde alcanza su medida (...) Está contenida toda la sabiduría pero sólo virtualiter o impliciter: en cambio, de presentarla actualiter y expliciter se ocupa la filosofía, que en este sentido es a aquellas lo que el vino a las uvas» ${ }^{78}$. La filosofía eleva la «intuición sucesiva y cambiante, y en general todo lo que el amplio concepto de sentimiento abarca y designa de forma meramente negativa como saber no abstracto y claro, para convertirlo precisamente en tal, en un saber permanente ${ }^{79}$.

Y sin embargo, el genio está lejos de ser un hombre feliz. Es más sensible al sufrimiento y conoce el fondo de la realidad. No se encuentra permanentemente inmerso en la experiencia de la creación artística ni puede activarla a voluntad. Y siempre tiene presente la experiencia de un mundo perdido y el contraste entre la vida cotidiana y la experiencia estética. Está condenado a «volver» al mundo fenoménico, una vuelta a la vulgaridad y a la soledad. No se reconoce en la sociedad en la que vive; difícilmente se entiende con los otros: es un extraño en medio de los hombres. En cuanto al hombre corriente, está atrapado en los intereses y demandas de la vida cotidiana. No es capaz de placeres puramente intelectuales. Para que algo capte su atención tiene que remitirlo a su voluntad, pues su vida consiste más en querer que en conocer. A lo sumo, es prudente y racional: busca en todo su provecho y su camino ${ }^{80}$. Y siempre que

\footnotetext{
Ídem.

Ídem.

Arthur Schopenhauer, El mundo como voluntad y representación, op. cit., 133. (W I, 123-124).

«Esa mercancía de la naturaleza como las que esta produce miles a diario, no es capaz de una consideración desinteresada en todos los sentidos, que es lo que constituye la verdadera contemplación, o al menos no de forma sostenida: él sólo puede dirigir su atención a las cosas en la medida en que tengan alguna relación, aunque sea muy mediata, con su voluntad (...) Por eso lo despacha todo tan rápido: las obras de arte, los objetos bellos de la naturaleza y los aspectos importantes de la vida en todas sus escenas (...) En la vida no busca más que su camino y, en todo caso, cualquier cosa que en alguna ocasión pudiera convertirse en su camino (...) No pierde el tiempo examinando la vida tal cual es». Ibíd., 241-242. (W I, 242).
} 
no los encuentra concluye: «No me sirve de nada». El conocimiento es para él «la linterna que alumbra su camino»; para el genio es «el sol que le hace patente el mundo» ${ }^{81}$. Pero la capacidad del genio ha de existir en algún grado en todos los hombres. De lo contrario no seríamos capaces de disfrutar de las obras de arte, no tendríamos sensibilidad para lo bello y lo sublime. Esta capacidad universal sirve también para extrañarnos de nosotros mismos ${ }^{82}$, distanciarnos y sorprendernos, para volver transformados. Tenemos entonces a nuestra disposición un gran remedio. Sin embargo, está en una región cercana solo en teoría, porque escapa a nuestro control y solo se cumple perfectamente en el genio, quien a lo sumo puede cedernos sus ojos (las obras de arte) para compartir durante un tiempo algo de lo que él ha experimentado. La obra de arte nos facilita acercarnos a la Idea. El artista ha captado esta en sí misma y la reproduce en su obra omitiendo «todas las contingencias que la perturban» ${ }^{83}$. El arte requiere, sin embargo, colaboración del espectador: el artista no ofrece todo a los sentidos, excita la fantasía y deja siempre algo que pensar. Las obras de arte incrementan la capacidad cognoscitiva del hombre medio, si bien hablan a cada uno según el nivel y profundidad de su inteligencia: «las obras más excelentes (...) tienen que permanecer como libros eternamente cerrados para la torpe mayoría de los hombres y les resultan totalmente inasequibles» ${ }^{84}$.

En la objetividad que posibilita la experiencia estética, y que es común también a la moral, a la ascética y a la intuición filosófica, hay algo análogo a cierta experiencia de eternidad o de inmortalidad ${ }^{85}$. La mente es eterna en la medida en que concibe la cosa bajo la especie de eternidad, había dicho Spinoza y recoge Schopenhauer. En este,

81 Ibíd., 242. (W I, 242).

82 «Hemos de suponer en todos los hombres aquella capacidad de conocer en las cosas sus ideas y, con ello, de extrañarse momentáneamente de su personalidad». Ibíd., 249. (W I, 250).

Ibíd., 249. (W I, 251).

Ibíd., 289. (W I, 296).

«Se percata inmediatamente de que él es en cuanto tal la condición, el soporte del mundo y de toda existencia objetiva (...) Él implica a la naturaleza en sí mismo de modo que la siente como un accidente de su ser (...) ¿ Pero cómo podría quien eso siente, considerarse a sí mismo como absolutamente perecedero por oposición a la naturaleza imperecedera?». Ibíd., 235. (W I, 234-235). 
en la certeza de que no somos solo fenómeno, sino también voluntad eterna, habría un atisbo de inmortalidad ${ }^{86}$ y en esa medida incluso una respuesta específica a la necesidad metafísica, como inútilmente mostraba Filaletes a Trasímaco. Aunque, paradójicamente, a esa experiencia solo puede accederse en esta vida y asociada a momentos puntuales de ruptura con la conciencia empírica. Tampoco nos remite necesariamente a la negación del mundo, sino que nos lanza a algo que nos supera pero de lo que formamos parte. Por otro lado, la reflexión de Schopenhauer sobre el arte no es solo una meditación sobre la inspiración del genio, ni solo sobre las obras de los museos o las Bellas Artes. La experiencia estética supone una reflexión más profunda sobre la realidad y dispensa una técnica, o una medicina del alma, útil para la vida y que consiste en su objetivación: en transformarla para mejor asimilarla.

Generalmente se subraya el extraordinario valor que tiene la música para Schopenhauer. Pero la tragedia, afirma el autor, es más importante porque habla de nosotros mismos. Su materia es el grado más alto de objetivación de la voluntad: el hombre. La idea de humanidad se despliega en ella para mejor ofrecérnosla. Nos revela el aspecto aterrador de la vida, brindándonos el espectáculo de la miseria humana, la victoria del azar y del error, la pérdida de los justos y el triunfo de los malvados. Y a través de esto, la representación de lo que es la realidad: una misma voluntad que vive en todos, pero cómo se combaten y despedazan, sin embargo, sus fenómenos. La tragedia forma parte de las artes poéticas ${ }^{87}$ y es un

86 «Puede que el hombre, si ha captado este punto de vista y se mantiene en él, se consuele con razón de su propia muerte y la de sus amigos volviendo la mirada a la vida inmortal de la naturaleza, que es él mismo». Ibíd., 332. (W II, 349).

87 «El poeta es el hombre universal: todo lo que ha conmovido el corazón de algún hombre, lo que en alguna situación la naturaleza humana ha dado de sí, lo que algún lugar habita y se gesta en un corazón humano, es su tema y su materia; como también todo el resto de la naturaleza (...) Nadie puede prescribirle al poeta que sea noble y sublime, moral, piadoso, cristiano, o que esa esto o aquello; y aún menos censurarle que sea esto y no aquello. Él es el espejo de la humanidad que le hace consciente de todo lo que siente y le agita». Ibíd., 305. (W I, 314). En Senilia, el cuaderno que inicia en 1852, se refiere a una especie de compasión estética: «el gran poeta dramático, lo mismo que el virtuoso, es tal a través de un tat twam asi [eso eres tú], de una identificación inmediata con otros (las personas de su drama), en todo lo cual reencuentra su propia esencia, o más bien se traslada al interior de esa esencia y toma posesión ora de este, ora de aquel, habla desde él como un ventrílocuo...». Arthur Schopenhauer, Senilia. Reflexiones de un anciano (Barcelona: Herder, 2010), 132. 
tipo supremo de arte, vinculado a lo sublime dinámico. Lo bello, es lo que por su forma variada y a la vez determinada y clara, se convierte fácilmente en representante de su Idea. Lo sublime se suscita ante algo hostil al observador (una amenaza, un peligro, algo que nos empequeñece...), pero este se sobrepone y se entrega a su conocimiento como puro sujeto involuntario del conocimiento. Contempla aquellos fenómenos terribles captando solo su Idea. Permaneciendo en su contemplación, se eleva por encima de su querer y de todo querer. La tragedia nos pone en desacuerdo con la voluntad y nos complacemos con lo que se opone directamente a ella. El centro de la tragedia, nos dice Schopenhauer, no es lo que le ocurre al héroe. Siguiendo a este, comprendemos que «lo que él expía no son sus pecados particulares sino el pecado original, es decir, la culpa de la existencia misma» ${ }^{88}$ y lo que significa ser seres finitos. La tragedia es la representación de lo que los filósofos intentan explicar como existencia o finitud. Y nos hace ver que la vida no puede ofrecernos verdadera satisfacción y que no merece nuestro apego. Ahí radica el sentimiento de lo trágico, y por eso el valor que destaca por encima de todos, aunque no es el único, es la resignación.

La tragedia además apunta a un tipo de existencia totalmente distinto, otro mundo cuyo conocimiento no se nos puede dar más que indirectamente, como a través de una reclamación. Mediante la experiencia de lo sublime, el individuo lo que alcanza con mayor claridad es la duplicidad de la conciencia, lo que el joven Schopenhauer denominó la duplicidad entre la conciencia empírica y la «conciencia mejor» ${ }^{89}$ y con ello un mecanismo de redención y sentido: se siente a la vez

88 Arthur Schopenhauer, El mundo como voluntad y representación, op. cit., 309. (W I, 319).

89 La 'conciencia mejor' o 'mejor conciencia' (besseres Bewußtsein) es el fundamento de las primeras reflexiones de Schopenhauer y está vinculada a su teoría de la redención. No aparece en la obra publicada. Las primeras referencias lo sitúan en oposición a la conciencia empírica y se encuentran en los cuadernos de estudio de 1811 y 1812 en alusión a la evidencia matemática en Fichte, o a la diferencia entre la 'conciencia mejor' y la 'intuición intelectual' de Schelling. En la edición de A. Hübscher de los Manuscritos juveniles, la primera mención corresponde a la anotación número 35 y es de 1812; la última es la 286 y data de 1814, el año del que dice Schopenhauer que todas las bases de su filosofía estaban ya establecidas. Después el término como tal desaparece, no así lo que representa. Este tema lo he desarrollado en Encarnación Ruiz Callejón, «El concepto de 'conciencia mejor' en Schopenhauer», Pensamiento. Revista de investigación e información filosófica 63 (2007): 437-462. 
como frágil fenómeno de la voluntad que el menor golpe de aquellas fuerzas puede aniquilar, desamparado, una nada evanescente frente a enormes poderes; $y$, al mismo tiempo, como un eterno y tranquilo sujeto de conocimiento que, en cuanto condición de todo objeto, es el soporte de todo ese mundo; la terrible lucha de la naturaleza no es más que su representación, y él mismo, en la tranquila captación de las ideas, se halla libre y ajeno a todo querer y necesidad. Nos percatamos de que «nuestra dependencia de él [del mundo] queda abolida por su dependencia de nosotros (...) somos uno con el mundo y por eso su inmensidad no nos aplasta sino que nos eleva ${ }^{90}$.

Pero Schopenhauer distingue entre la tragedia griega y la moderna. En la primera, el héroe:

muestra sumisión ante el inexorable destino y la inflexible voluntad de los dioses, pero ninguna renuncia a la voluntad de vivir. Así como la indiferencia estoica se distingue radicalmente de la resignación cristiana porque solo enseña a soportar con tranquilidad y esperar serenamente el mal ineludiblemente necesario, del mismo modo los héroes trágicos de la Antigüedad muestran un constante sometimiento a los inexorables golpes del destino, mientras que la tragedia cristiana presenta la renuncia a la voluntad de vivir, el alegre abandono del mundo, en la conciencia de su falta de valor y nulidad ${ }^{91}$.

Schopenhauer destaca la superioridad de la tragedia moderna: «los antiguos no habían alcanzado todavía la cumbre y el fin de la tragedia y del conocimiento de la vida en general» ${ }^{92}$. Sin embargo, tanto la tragedia antigua como la moderna obligan al espectador a un ejercicio reflexivo sobre la existencia y lo colocan en la tesitura de elegir: negar o afirmar la voluntad. Schopenhauer pone así de relieve, por una parte, que el arte es un ejercicio metafísico; por otra, la existencia de dos actitudes e ideales culturales contrapuestos ante el sufrimiento, que luego Nietzsche analizará en profundidad: el ideal griego que, a pesar del sufrimiento, opta por el estoicismo y la afirmación de la voluntad de vivir; y el cristiano, que elige la negación y afirma otra existencia que pueda resarcirnos de esta.

Arthur Schopenhauer, El mundo como voluntad y representación, op. cit., 260. (W I, 263).

Arthur Schopenhauer, El mundo como voluntad y representación. Complementos, op. cit., 485. (W IV, 511).

Ídem. 
Las grandes desgracias a las que asistimos suelen deberse a un carácter de una maldad descomunal o pueden ser producto del ciego destino, ya sea el azar o el error. Pero en su escenificación de la finitud, la tragedia nos ofrece aún otra enseñanza. Schopenhauer se refiere a una tercera posibilidad mucho más terrible: el mal y el sufrimiento esencialmente próximos y cotidianos e imposibles de esquivar:

la desgracia puede ser producida por la mera posición recíproca de los personajes, por sus relaciones; de modo que no se requiere ni un enorme error o un inaudito azar, ni tampoco un individuo terriblemente malvado, sino que caracteres usuales en un sentido moral, en circunstancias como las que habitualmente se presentan, están colocados unos respecto a otros de tal forma que su posición les fuerza a causarse la mayor desgracia unos a otros sin que la injusticia esté exclusivamente de ningún lado. Este último tipo me parece que aventaja mucho a los otros dos: pues nos muestra la mayor desgracia no como una excepción (...) sino como algo que nace del obrar y el carácter de los hombres fácilmente y por sí mismo, casi como esencial a ellos; y de este modo nos lo trae a una terrible proximidad ${ }^{93}$.

En los casos en que la desgracia se debe a un terrible azar o a un carácter excepcionalmente malvado, nos sentimos a una gran distancia de seguridad, "pudiendo muy bien escapar de ellos sin refugiarnos en la renuncia ${ }^{94}$. Pero el último caso, lo que nos muestra son unos poderes destructores de la felicidad y de la vida, con los que todos tropezaremos, de los que ninguno estaremos jamás a salvo:

que tienen abierto en cualquier momento el camino hacia nosotros, pone ante la vista el sufrimiento máximo, producido por combinación de circunstancias que en esencia también podrían formar parte de nuestro destino y por acciones que quizá también nosotros seríamos capaces de hacer, así que no podríamos quejarnos ante la injusticia: entonces nos estremecemos y nos sentimos ya en el infierno ${ }^{95}$.

Y en ese sentido, ni siquiera la renuncia garantiza el éxito. En esa medida el arte, y especialmente la tragedia, podemos decir de nuevo que es un ejercicio metafísico, quizá el más completo, y una respuesta radicalmente profunda y matizada a la necesidad metafísica

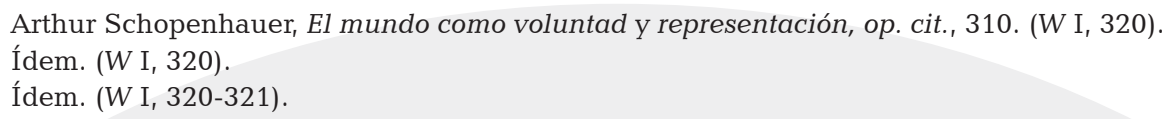


y que habla en un lenguaje que todos podemos comprender. En nada desmerece a las aportaciones de las religiones o de las filosofías. La literatura, y el arte en general, forman parte, con pleno derecho, de ese fondo de sabiduría de la humanidad.

\subsection{La liberación estética en el mundo fenoménico}

Pero no acaba aquí la reflexión tan matizada y poliédrica de Schopenhauer sobre la necesidad metafísica y sobre el arte. En los «Aforismos sobre la sabiduría de la vida», el texto más extenso de Parerga y Paralipómena, afirma que en él deja a un lado el punto de vista ético-metafísico de su obra fundamental, que adopta el «usual punto de vista empírico» y lo que llama «el error fundamental», la convicción de que «estamos aquí para ser felices». Es decir, el punto de vista del hombre común, aunque inmediatamente precisa que entiende por aquella convicción «ser lo menos infelices posible». Lo que no abandona es la actitud pesimista: la ausencia de fundamento y la fragilidad de todo lo humano, también a propósito de la vida en sociedad y del valor de los otros. Pero de nuevo aquí tampoco apuesta por la negación de la voluntad de vivir. Y está también muy presente la perspectiva o actitud estética, porque Schopenhauer nos invita a construirnos un «refugio ignífugo», «un puesto alpino», en el fondo un cierto escenario de ilusión, pero no por ello baladí, desde el que sea posible contemplar el mundo y continuar en él con la dignidad de una obra de arte de la Voluntad, mientras nos relacionamos con nuestros congéneres con la prevención de la fábula de los puercoespines ${ }^{96}$. Y en esta medida, hay en Schopenhauer un arte de vivir.

Un hombre así (que no es un genio, ni un santo, ni un asceta), junto a su vida personal cultiva otra: la intelectual. Y obtiene, a través de esta y de la perspectiva estética, una redención ideal, que Schopen-

\footnotetext{
96 Arthur Schopenhauer, "Metáforas, parábolas y fábulas", en Parerga y Paralipómena II, op. cit., 665. "La distancia intermedia que al final encuentran y en la cual es posible que se mantengan juntos es la cortesía y la buenas costumbres». (W X, 709).
} 
hauer identifica con la atmósfera de los dioses de vida fácil ${ }^{97}$. Desde esta posición todo es bello, dice Schopenhauer, porque todo expresa algún grado de objetivación. Algo es más bello que otra cosa, porque facilita la contemplación objetiva, la fomenta y hasta obliga a ella. En este sentido, afirma que el hombre -el grado más alto de objetivación de la voluntad- ha de ser es el más bello de los seres y la revelación de su esencia es el fin supremo del arte, como ocurre en la tragedia. Pero aquí nos encontramos con otra enseñanza de esta, pues Schopenhauer se refiere a lo «sublime ético». El carácter sublime no es aquí el de un individuo extraordinariamente compasivo, absolutamente bueno. Es sublime en tanto que, aún siendo consciente de los horrores que también se muestran en el comportamiento de los hombres, se repone. Precisamente lo sublime, nos permite adoptar aquí esa perspectiva superior que caracteriza a la experiencia artística. Entonces ese mismo individuo que es consciente de todo lo humano, terriblemente humano, pasa a considerar la idea de la humanidad, no a los hombres concretos y conforme a las relaciones que pudieran tener con la propia voluntad. Así por ejemplo, observará sus defectos, incluso su odio y su injusticia hacia él mismo, sin que por su parte se suscite una reacción. Del mismo modo verá sus buenas cualidades, su felicidad o su desdicha: sin desear una relación más cercana con ellos. Todo ello ni le afligirá ni le alegrará, dedicándose más a conocer que a sufrir y a compadecer, a padecer $\operatorname{con}^{98}$. En este sentido, la objetivación estética parece ser la última mirada al mundo y la más curativa y saludable. Es la que permite el desapego del genio, del santo, del asceta, pero también del filósofo y del hombre medianamente dotado. Es la de Schopenhauer

«Homero, la expresión más pura del mundo antiguo, nos presenta el desgarro, la marcha, las disputas y los alborotos del mundo tal como son, objetos para nuestra conciencia empírico-racional. Pero la 'mejor conciencia', que reina en las profundidades de nuestro fuero interno sin verse perturbada ni afectada por todas estas cosas, queda objetivada y (al igual que las fuerzas de la naturaleza) personificada en aquellos beatíficos e inmortales dioses que asisten tranquilamente al espectáculo de todo este barullo desde la platea del Olimpo y para quienes todo ello no pasa de ser una chanza...» Arthur Schopenhauer, Manuscritos berlineses, op. cit. (HN I, 187, 103). Aquí tenemos, en este apunte previo a la metafísica de la voluntad, cierta adhesión del joven Schopenhauer a la justificación griega de la existencia.

98 Arthur Schopenhauer, El mundo como voluntad y representación, op. cit., 261. (W I, 264-265). Y cita a Goethe: «Al que ve la belleza humana no le puede dañar ningún mal: se siente en consonancia consigo mismo y con el mundo». Ibíd., 275. (W I, 281). 
en los «Aforismos», en Parerga y Paralipómena, su última obra y quizá también su ideal personal, pues él ciertamente no practicó la negación de la voluntad. Y coincide con dos de las enseñanzas más características de la tragedia: la humanidad como materia de reflexión y la consciencia de los poderes destructores de la felicidad y la vida. Sin embargo, nos permite reconciliarnos con la existencia asumiendo su falta de fundamentación. Contiene la única moral de la que somos en realidad más capaces, pues -excepto casos muy aislados-no podemos identificarnos siempre -no ya sólo con el dolor-sino con las miserias de los hombres concretos e incluso con el sufrimiento de todos los seres, como lo hace ese ejemplar tan raro que es el hombre absolutamente compasivo. La objetivación estética amortigua el sufrimiento, transforma los aspectos negativos de la existencia sin rehuirlos, aunque considerando todo a otra luz. Puede reconciliarnos con la existencia y con la humanidad, incluso con el pasado ${ }^{99}$. Si tenemos en cuenta que todo lo existente puede ser considerado de forma puramente objetiva y fuera de toda relación; y que todo manifiesta la voluntad en algún grado de su objetivación y expresa por ello una Idea, se sigue que todas las cosas son bellas, consecuentes con su posición.

Schopenhauer anima, incluso, a no desaprovechar lo que nos ofrezca el presente, especialmente la alegría. El presente es lo único seguro y a la alegría hay que abrirle las puertas, y acogerla sin preguntarnos si tenemos razón o no para estar alegres -nos dice en los «Aforismos»-, pues nunca llega en mal momento y es una ganancia segura ya que nos hace inmediatamente felices. Del mismo modo, no olvida el género opuesto a la tragedia clásica, que es por el que opta en los «Aforismos»: la comedia, porque a su modo pone de relieve un aspecto esencial de la vida: su lado cómico, su vertiente humorística. Y con ello es un remedio más para relativizar, aligerar, el peso de la existencia. No es, pues, un arte menos profundo.

99 «Podemos sustraernos a todo sufrimiento tanto a través de los objetos presentes como de los remotos, tan pronto como nos elevamos a la consideración puramente objetiva de los mismos y somos capaces de crear la ilusión de que solo están presentes aquellos objetos y no nosotros mismos». Ibíd., 253. (W I, 255). 


\section{Conclusiones}

Siguiendo la reflexión del autor en los textos sobre las dos formas de responder a la necesidad metafísica (la religión y la filosofía) y los «Aforismos», y profundizando en su reflexión sobre el arte, que es extraordinariamente compleja y llena de matices, nos encontramos que en el mundo como voluntad y como representación, queda abierta también una vía para aquellos que profesan el pesimismo, sí, pero el de la fortaleza. El arte aparece como un medio para dar respuesta a la necesidad metafísica y conduce a un arte de vivir para una nueva época y para un hombre que esté de vuelta de los grandes ideales y relatos y que asuma la ausencia de fundamento de la realidad.

Entre las acepciones del término «redención», el Diccionario señala las de «remedio», «recurso», «refugio». En los «Aforismos» Schopenhauer no se refiere a la negación de la voluntad, sino a un «arte» que nos permita utilizar y rentabilizar fuerzas y recursos, propios de la condición humana, en los que a veces no repara la filosofía pero sí recoge la literatura. La filosofía y la religión son, en el fondo, una forma de arte:

El modo verdaderamente filosófico de considerar el mundo (...), aquel que nos da a conocer su esencia interna y nos conduce así más allá del fenómeno, es precisamente el que no pregunta por el de dónde, adónde y por qué, sino exclusivamente por el qué del mundo (...), el que considera las cosas no según alguna relación, no en cuanto naciendo y pereciendo, sino que, al contrario, tiene por objeto precisamente lo que queda tras eliminar toda aquella forma de consideración que rige el principio de razón, la esencia del mundo siempre igual que se manifiesta en todas las relaciones pero no está sometida a ellas, sus ideas. Como el arte, también la filosofía parte de tal conocimiento, y de él nace incluso (...) el único estado de ánimo que conduce a la verdadera santidad y a la liberación del mundo ${ }^{100}$.

En el fondo: «Toda filosofía y cualquier consuelo brindado por ella no consisten sino en la constatación de que hay un mundo sobrenatural donde, separados de todos los fenómenos del mundo externo,

100 Arthur Schopenhauer, El mundo como voluntad y representación, op. cit., 330. (W II, 346-347). 
podemos contemplarlos desde un alto pedestal con el sosiego de no vernos involucrados en ellos» ${ }^{101}$. Nietzsche también afirmará que «"idealizar" significa extraer los rasgos capitales, de tal modo que los demás desaparezcan ante ellos» ${ }^{102}$. "Este tener-que-transformar las cosas en algo perfecto es arte» ${ }^{103}$. El resultado es el enriquecimiento de todas las cosas con la propia plenitud: todo aparece enriquecido, «sobrecargado de energía» ${ }^{104}$. Esta es la virtud, junto con la honestidad intelectual (una cualidad que también Nietzsche encontró en la filosofía de Schopenhauer), que desarrolla el espíritu heroico o aristocrático. Es también la perspectiva suprahistórica de la Segunda Intempestiva, la de las potencias que desvían la mirada del devenir e imprimen a la existencia un carácter de eternidad: la religión y el arte. Schopenhauer, el filósofo del pesimismo, puede entonces decir con Nietzsche, en El nacimiento de la tragedia: «sólo como fenómeno estético están justificados la existencia y el mundo». Aquí Nietzsche, como se sabe, suscribe la metafísica de la voluntad schopenhaueriana del «dios» artista, aunque ya en tensión con el ideal griego de la existencia y con la tragedia griega. Más allá de la metafísica de artista, y al hilo de la voluntad de poder y de la consideración de la religión en Grecia, Nietzsche adoptará el punto de vista de la vida por lo que nuestra suprema dignidad es ser obras de arte, es decir, secundar y conmemorar nuestra condición. En el Nietzsche que deja atrás la impronta de Schopenhauer, el hombre es fundamentalmente un artista y el arte será el medio de justificar la propia biografía, de darle sentido y estilo. Pero en Schopenhauer existe también esa función en el arte como arte de vivir y como cierta fidelidad a la tierra, como hemos visto: muy débil en su obra fundamental, pero muy presente en los textos y en el estilo y objetivo de Parerga y Parerga, su última obra y un texto que Nietzsche conocía. En este sentido, creo que hay que modular la caracterización tradicional de Schopenhauer como

101 Arthur Schopenhauer, Escritos inéditos de juventud (1808-1818). Sentencias y aforismos II (Valencia: Pre-Textos, 1999), 25. (HN I, 7-8, [1]).

102 Friedrich Nietzsche, Crepúsculo de los ídolos (Madrid: Alianza, 1993), 91. (KSA VI, 116).

103 Ídem. (KSA VI, 117).

104 Ídem. 
filósofo del pesimismo y la negación de la voluntad, y revisar las críticas de Nietzsche a su maestro en este sentido ${ }^{105}$ y la distancia respecto a él, cuestiones estas últimas que aquí sólo dejo apuntadas.

Volviendo a la capacidad estética, quizá fuese este mismo recurso y medicina del alma al que hacía referencia Aristóteles en relación a la vida contemplativa, la actividad humana que más se parece a la divina:

tal vida, sin embargo, sería superior a la de un hombre, pues el hombre viviría de esta manera no en cuanto hombre, sino en cuanto que hay algo divino en él (...). Si, pues, la mente es divina respecto del hombre, también la vida según ella será divina respecto de la vida humana. Pero no hemos de seguir los consejos de algunos que dicen que, siendo hombres, debemos pensar sólo humanamente y, siendo mortales, ocuparnos sólo de las cosas mortales, sino que debemos, en la medida de lo posible, inmortalizarnos y hacer todo esfuerzo para vivir de acuerdo con lo más excelente que hay en nosotros ${ }^{106}$.

Diotima, por cierto una mujer, ya había mostrado al Sócrates platónico el mismo camino:

En ese instante de la vida, querido Sócrates (...), más que en ningún otro, vale la pena el vivir del hombre: cuando contempla la belleza en sí (...) ¿̇Acaso crees -prosiguió- que llega a ser vulgar la vida de un hombre que pone su mirada en eso, lo contempla con lo que debe contemplarlo y está en su compañía? ¿ O no piensas -dijo- que solamente en ese momento, cuando vea la belleza con lo que es visible, podrá engendrar no imágenes de virtud, ya que no está en contacto con una imagen, sino virtudes verdaderas, al estar en contacto con la verdad? Y a quien ha engendrado una virtud verdadera y la ha criado, ¿no piensas que le es dado hacerse amigo de los dioses y, si es que a algún hombre le es dado, inmortal también él? ${ }^{107}$.

Desde esta perspectiva podemos sospechar que incluso en la promesa de la serpiente, "Seréis como dioses», había quizá mucho más que engaño e incitación a la desobediencia: un extraordinario enigma sobre nuestra dualidad constitutiva, una indicación que no

He tratado las líneas fundamentales de las mismas en: Nietzsche y la filosofía práctica. La moral aristocrática como búsqueda de la salud (Granada: Universidad de Granada, 2004), especialmente en las páginas 53-68 y 244-262.

106 Aristóteles, Ética a Nicómaco (Madrid: Gredos, 1985), 397-398.

107 Platón, El banquete (Madrid: Alianza, 2005), 122-123. 
se refiere sólo a la expulsión por la soberbia del conocimiento, sino al camino de vuelta a cierto Paraíso, también a través del conocimiento, pero ya purificado y como contemplación.

\section{Bibliografía}

Aristóteles. Ética a Nicómaco. Madrid: Gredos, 1985.

Barnavi, Élie. Las religiones asesinas. Madrid: Turner, 2007.

Broese, Konstantin et ál. (Hrsg.). Die Deutung der Welt. Jörg Salaquardas Schriften zu Arthur Schopenhauer. Würzburg: Verlag Königshausen \& Neumann GmbH, 2007.

Huntington, Samuel P. El choque de civilizaciones y la reconfiguración del orden mundial. Barcelona: Paidós, 2005.

Kant, Inmanuel. Crítica de la razón pura. Madrid: Alfaguara, 1978.

Kruck, Günter. «Zur Rationalität der Religion. Schopenhauer und sein Verhältnis zu einem neuen Strang von Religionsphilosophie», Jahrbuch der Schopenhauer-Gesellschaft (2010): 121-134.

Maceiras Fafián, Manuel. «La Voluntad como energía», Logos. Anales del Seminario de Metafísica 23 (1989): 119-134.

Magee, Bryan. Schopenhauer. Madrid: Cátedra, 1991.

Mannion, Gerard. Schopenhauer, Religion and Morality. The Humble Path to Ethics. England: Ashgate Publishing Limited, 2003.

Nietzsche, Friedrich. El nacimiento de la tragedia. Madrid: Alianza, 1991.

. Sobre la utilidad y el perjuicio de la historia para la vida [II Intempestiva]. Madrid: Biblioteca Nueva, 1999.

. Schopenhauer como educador. Madrid: Biblioteca Nueva, 2000.

. La genealogía de la moral. Madrid: Alianza, 1987. 
. Ecce homo. Madrid: Alianza, 1987.

. Crepúsculo de los ídolos. Madrid: Alianza, 1993.

Platón, El banquete. Madrid: Alianza, 2005.

Ruiz Callejón, Encarnación. «La 'tercera navegación' en Schopenhauer: el carácter adquirido y el arte de vivir». Daimon. Revista de Filosofía 31 (2004), pp. 23-42.

- Nietzsche y la filosofía práctica. La moral aristocrática como búsqueda de la salud. Editorial Universidad de Granada, 2004.

. EEl concepto de 'conciencia mejor' en Schopenhauer», Pensamiento. Revista de investigación e información filosófica 63 (2007): 437-462.

Ryan, Christopher. Schopenhauer's Philosophy of Religion. The Death of God and the Oriental Renaissance. Leuven: Peeters, 2010.

Safranski, Rüdiger. Schopenhauer y los años salvajes de la filosofía. Madrid: Alianza, 1991.

Schmidt, Alfred. Die Wahrheit im Gewande der Luge: Schopenhauers Religionsphilosophie. Múnich, Zúrich: Piper, 1986.

Schopenhauer, Arthur. Werke in zehn Bänden. Zürich: Diogenes Verlag, 1977.

. Der handschriftliche Nachlass in fünf Bänden. München: Deutscher Taschenbuch Verlag, 1985.

. El mundo como voluntad y representación. Madrid: Trotta, 2004.

. El mundo como voluntad y representación. Complementos. Madrid: Trotta, 2003.

. Los dos problemas fundamentales de la ética. "Sobre el fundamento de la moral». Madrid: Siglo XXI, 1993. . Parerga y Paralipómena I. Madrid: Trotta, 2006. 
. Parerga y Paralipómena II. Madrid: Trotta, 2009.

. Parerga y paralipomena. Tomo primo. Milano: Adelphi Edizioni, 1981.

. Escritos inéditos de juventud (1808-1818). Sentencias y aforismos II. Valencia: Pre-Textos, 1999.

. El dolor del mundo y el consuelo de la religión (Paralipomena 134-182). Madrid: Alderabán, 1998.

. Manuscritos berlineses. Sentencias y aforismos (Antología) . Valencia: Pre-Textos, 1996.

. Epistolario de Weimar (1806-1819). Selección de cartas de Johanna, Arthur Schopenhauer y Goethe. Madrid: Valdemar, 1999.

. Senilia. Reflexiones de un anciano. Barcelona: Herder, 2010.

Wallace, William. Arthur Schopenhauer. Barcelona: Ediciones de Nuevo Arte Thor, 1988.

Wilhelm, Karl W. Zwischen Allwissenheitslehre und Verzweiflung: der Ort der Religion in der Philosophie Schopenhauers. Hildesheim; New York: G. Olms, 1994.

Zimmer, Robert. Arthur Schopenhauer. Ein philosophischer Weltbürger. München: Deutscher Taschenbuch Verlag, 2010.

Recibido: 24 de junio de 2012

Aceptado: 29 de noviembre de 2012 